\title{
Brincando com os padrões: a arte de criar estampas
}

Playing with tessellation: the art of creating patterns

\section{Ana Helena Soares Cavalcanti \\ Mestre em Design pela Universidade Federal de Pernambuco anahelena.pe@gmail.com \\ Maria Alice Vasconcelos Rocha}




\section{Brincando com os padrões: a arte de criar estampas}

Playing with tessellation: the art of creating patterns

\section{Ana Helena Soares Cavalcanti e Maria Alice Vasconcelos Rocha}

\section{Resumo}

A proposta deste artigo consiste em trazer técnicas para a configuração de estampas a partir de formas geométricas, como quadriláteros, triângulos e hexágonos, juntamente com a simetria. Buscando referências nos Fundamentos do Design de Superfície apresentados por Rüthschiling (2008), assim, busca-se trazer conceitos básicos para compreender o processo de configuração do design de superfície passando pelas etapas: Escolha do tema [temática]; Elaboração dos elementos/motivos; Escolha das cores; Construção do Módulo; Repetição [Geração de alternativas]. Cabe ressaltar, que este artigo pretende trabalhar com o conceito de Rapport que é um modelo utilizado para configurar padrões diferentes tendo como base um mesmo módulo, mudando, por exemplo, a direção ou rotação de seus encaixes - geralmente neste modelo a figura base do módulo é o quadrado ou retângulo. Porém, neste artigo busca-se demonstrar como utilizar outras formas geométricas [como hexágonos e triângulos].

Palavras-chave: Estampa, Design, Técnica.

\begin{abstract}
The purpose of this article is to bring techniques for patterns setting from geometric shapes, such as quads, triangles and hexagons, along with symmetry. Seeking references in the Surface Design Fundamentals presented by Rüthschiling (2008) thus seeks to bring basic concepts to understand the setup process surface design going through the steps: Choose theme [theme]; Development of elements / reasons; Choice of colors; Construction of the module; Repeat [Generation alternatives]. It is worth mentioning, this article intends to work with the concept of Rapport is a model used to set different standards based on the same module, changing, for example, the direction or rotation of their cash - usually in this model the module base figure is the square or rectangle. However, this article seeks to demonstrate how to use other geometric shapes [as hexagons and triangles].
\end{abstract}

Keywords:Pattern, Design, Techniques. 


\section{Introdução}

Dentre as características inerentes no Design destaca-se por ser uma área multidisciplinar que está presente em várias atividades dos sujeitos, desta forma, contempla uma variedade de setores cujo objetivo é atender as necessidades dos usuários sejam elas estéticas e/ou funcionais. É plausível afirmar que a primeira Revolução Industrial foi o estopim para se consolidar a área do Design como sendo algo relevante no processo industrial. Com isso, alguns profissionais começam a ganhar espaço na indústria, dentre eles os que trabalham com a configuração de padrões.

Nota-se que esta área não se restringe apenas a têxtil, pois esta arte de criar padrões pode ser aplicada em outros setores como de cerâmicas e papéis de paredes. Com o tempo o Design de Superfície se comporta como um campo que está conquistando o seu espaço tanto no círculo científico como no mercado brasileiro. Isto ocorre justamente por esta ser uma atividade nova no Brasil, todavia, existem alguns pesquisadores que se dedicam ao estudo, seja na geração ou registro de informações, podendo ser destacada a atuação de Rüthschiling (2008). Este fato acarreta como um motivo relevante para aprofundamento de pesquisas nesta área do design.

A superfície aplicada num artefato influencia na percepção [sentidos] do sujeito em querer olhar e/ou sentir o artefato, pois a mesma apresenta características atreladas à estética do objeto. Löbach (2001) afirma que a função estética remete a um mecanismo que envolve a relação artefato e sujeito por meio de processos sensoriais, onde o designer tende atribuir ao artefato conceitos, formas, detalhes, isto é, ele procura projetar novos olhares para cativar o sujeito. Cipiniuk (2011) reafirma a responsabilidade de aplicar a estética nos artefatos, isto se deve ao fato que o designer contém o conhecimento de fazer conexões com os aspectos simbólicos e estéticos, ou ainda, de trabalhar as características culturais [valores] juntamente com as utilidades do objeto. A estética a partir desses fundamentos se comporta como um aspecto relevante para a configuração de artefatos, este artigo procura trazer, além de fundamentos e técnicas, o processo de configuração de Design de Superfície.

\section{Fundamentos do Design de Superfície}


Estes se referem ao processo de criação de padronagens em que para isto é necessário princípios básicos, desta forma, Rüthschilling (2008) relata que antes de configurar um padrão é de primordial importância o designer se apropriar dos conceitos referentes ao módulo e os seus sistemas de repetição. Tendo isto como objetivo, esta autora apresenta etapas a serem seguidas, sendo elas:

Módulo e sua construção

O módulo é a menor extensão que inclui todos os elementos da padronagem (RÜTHSCHILLING, 2008). Este pode apresentar um formato de uma figura geométrica ou ainda ser algo amórfico. Na prática, com o advento da computação [tecnologia]; o módulo tende a ser um quadrilátero, em advento do pixel. A Figura 1 ilustra dois tipos de módulos.

Figura 1- Exemplos de módulos.

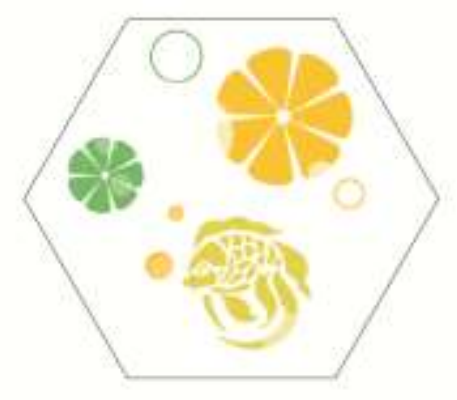

Módulo 01

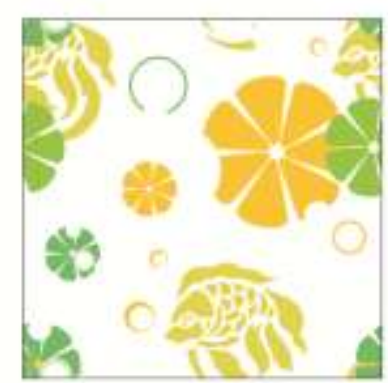

Módulo 02

Fonte: Próprio autor

\section{Encaixe}

Refere-se ao modo de analisar os limites do módulo para ajustar os elementos que serão dispostos no mesmo lado, a Figura 2 ilustra o encaixe do Módulo 02 [Figura 1]. 
Figura 2 - Passo a passo construção do módulo com encaixe.

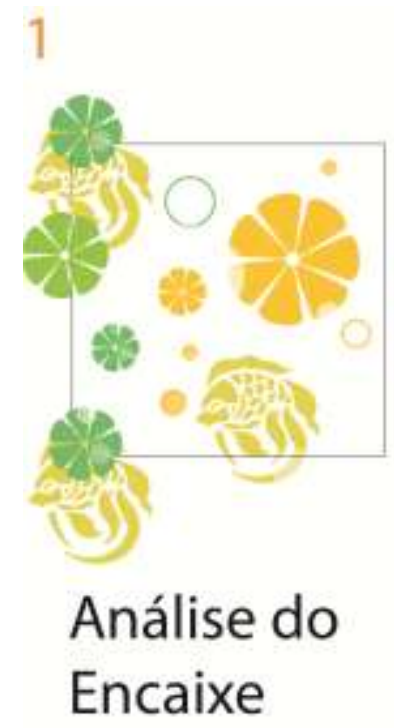

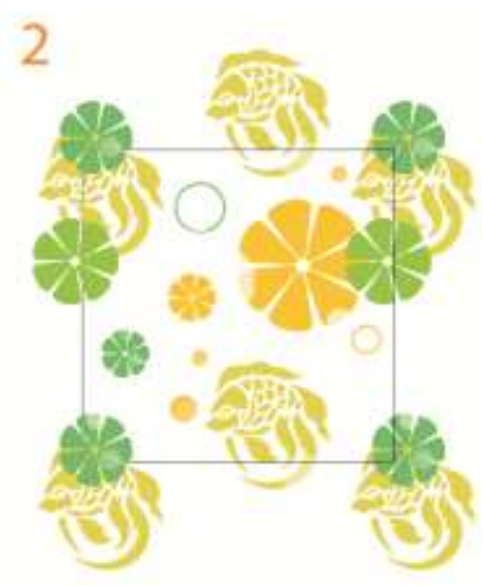

Após a análise

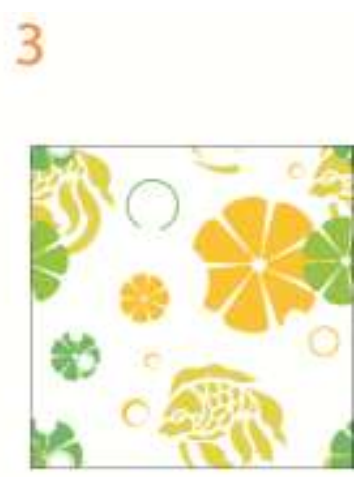

Módulo

Fonte: Próprio autor

Cabe ressaltar um cuidado que deve ter com os encaixes do módulo, pois, articulando os encontros de suas extremidades pode resultar numa repetição mais fluida. Segundo Rüthschilling (2008), existem dois princípios que se conectam com os estudos relacionados ao Encaixe, são eles: Continuidade e Contigüidade. O primeiro se refere a uma repetição ordenada sem interrupções [quebras] dos elementos visuais. Já a Contigüidade está conectada com "[...] harmonia visual na vizinhança dos módulos, estado de união visual." (RÜTHSCHILLING, 2008, p. 65).

Composição sem Encaixes

Trata-se do tipo de módulo que não apresenta uma continuidade em suas fronteiras bem como a falta de certos elementos e a aparecimento de outros (RÜTHSCHILLING, 2008), ou seja, no decorrer da repetição do módulo varia os elementos como pode ser observado na Figura 3. 
Figura 3 - Exemplo de uma Superfície sem Encaixe.

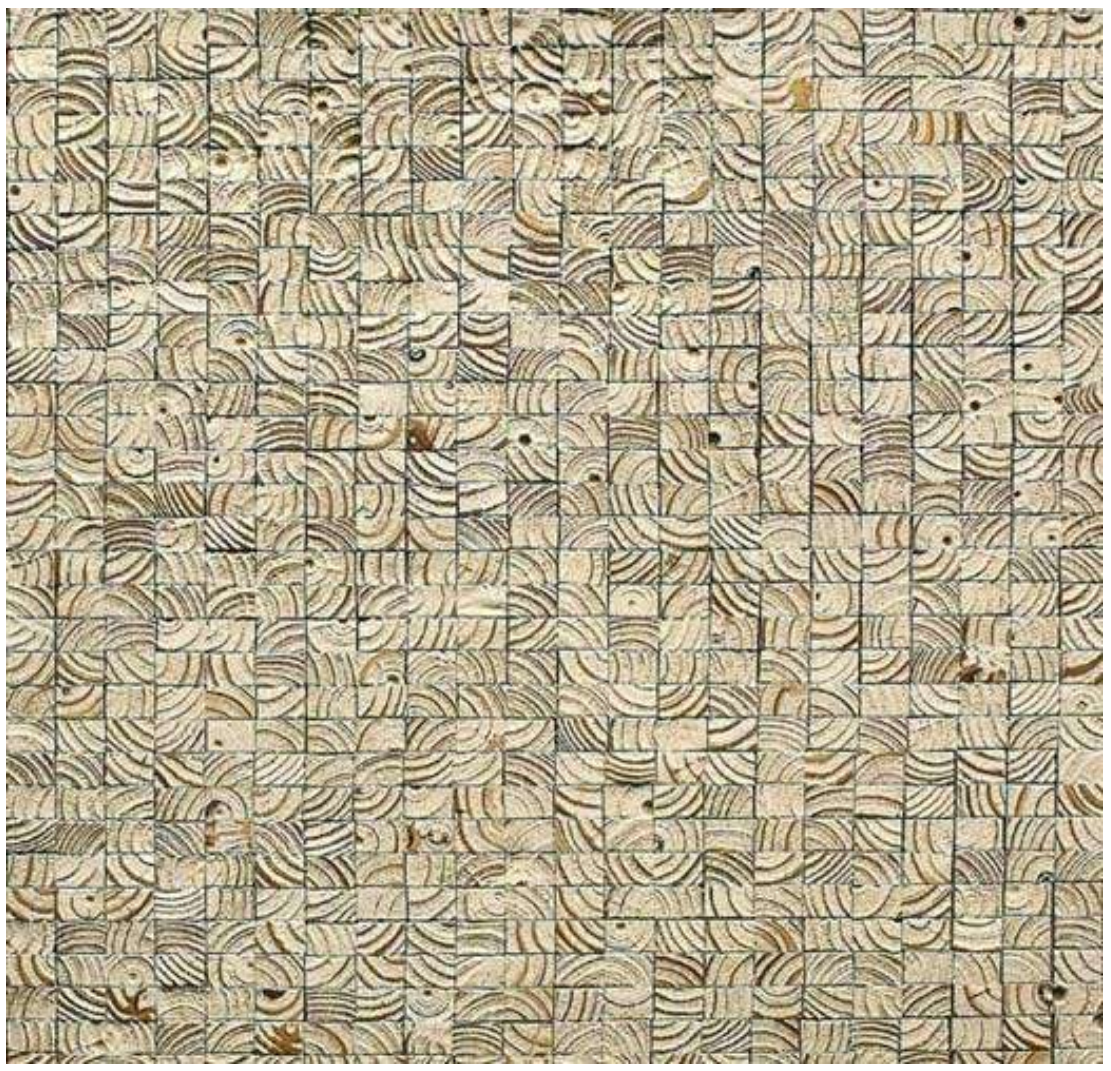

Fonte: Contém Design, 2013c

Sistemas de Repetição

Refere-se ao modelo que o designer opta para reproduzir o módulo na superfície, ou seja, o sistema de repetição é justamente o modo de dispor sequencialmente a forma. Com isso, cabe ao designer a escolha do sistema mais adequado ao projeto - levando em consideração a harmonia, continuidade, forma, entre outros aspectos relacionados ao design. Os sistemas de Repetição são três [alinhados, não-alinhados e progressivos] em que eles partem de princípios referentes a simetria para variar o posicionamento do módulo na superfície sendo eles translação, rotação e reflexão. A Figura 4 ilustra tipos de sistemas de repetição. Neste caso a grade de repetição é quadriculada em que serve como um guia para repetir o módulo na superfície. 
Figura 4 - Tipos de Sistemas de Repetição.

Módulo

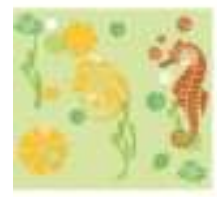

Sistema de Repetiçăo

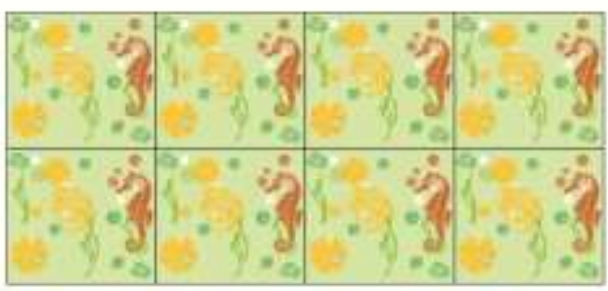

Alinhados Utilizando da Translação

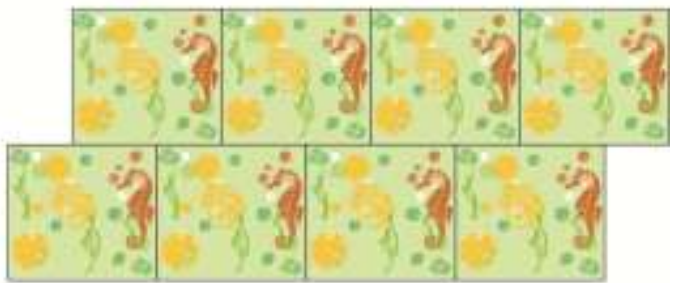

Náo Alinhados Utilizando da Translaçăo

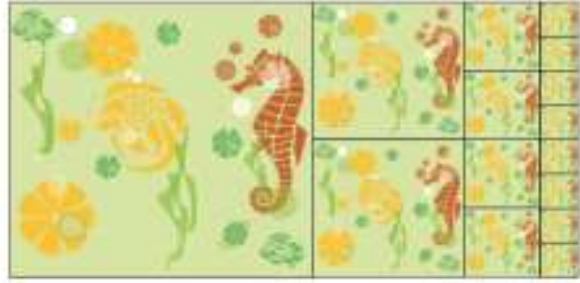

Progressivos Utilizando da Translação

Fonte: Próprio autor.

Multimódulo

O multimódulo tem sua origem a partir da repetição do módulo em que dependendo da maneira que ele é manipulado [Sistemas de Repetição] pode gerar composições diferentes. Desta forma, o Multimódulo é formado a partir de um conjunto de quatro módulos, a Figura 5 abaixo ilustra um módulo R sendo articulado com dois tipos de simetria [translação, rotação]. Como pode ser observado na figura abaixo existe dois multimódulos [em azul] diferentes em 
que no segundo sistema de repetição o ' $R$ ' é rotacionado gerando um padrão diferente do primeiro

Figura 5 - Exemplo Múltimódulo.

Módulo

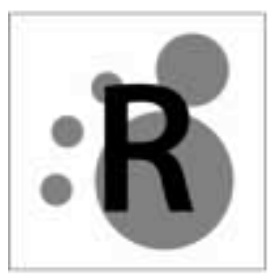

Multimódulo

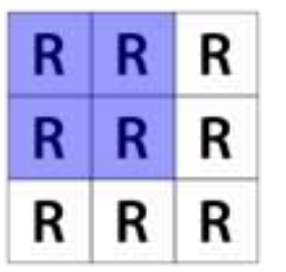

Sistema de Repetição 1

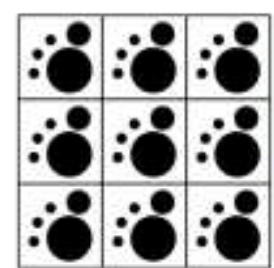

Padrão 1

Fonte: Próprio autor

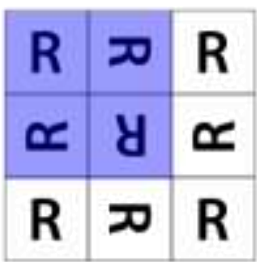

Sistema de Repetição 2

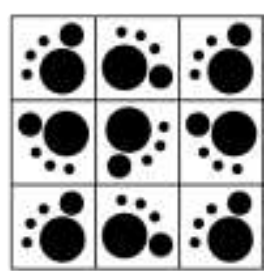

Padrão 2

\section{Conceitos de Simetria}

Observa-se que a simetria está presente na natureza, em artefatos criados pelo homem, ou ainda em obras artísticas (JABLAN, 1995). Por exemplo, dois pontos distintos são considerados simétricos “[...] em relação a uma reta se e somente se o segmento da reta que une estes dois pontos é dividido ao meio e normalmente pela referida reta." (LEHMANN,1998,p. 30). A Figura 6 apresenta dois pontos equidistantes em relação à reta $\mathrm{r}$ - comprovando o conceito de Lehmann (1998). Assim, a reta $\mathrm{r}$ é utilizada como eixo de simetria que reflete a bola a uma mesma distância $\mathrm{x}$ do lado oposto, tornando as bolinhas A e B simétricas em relação à reta r. Este tipo de simetria é chamada de Reflexão [simetria reflexional] em que existe um eixo o qual reproduz do lado contrário da imagem original. A Figura 7 ilustra três eixos de simetria: vertical [a], horizontal [b], e inclinado [c]. 
Figura 6 - Exemplo de Simetria.

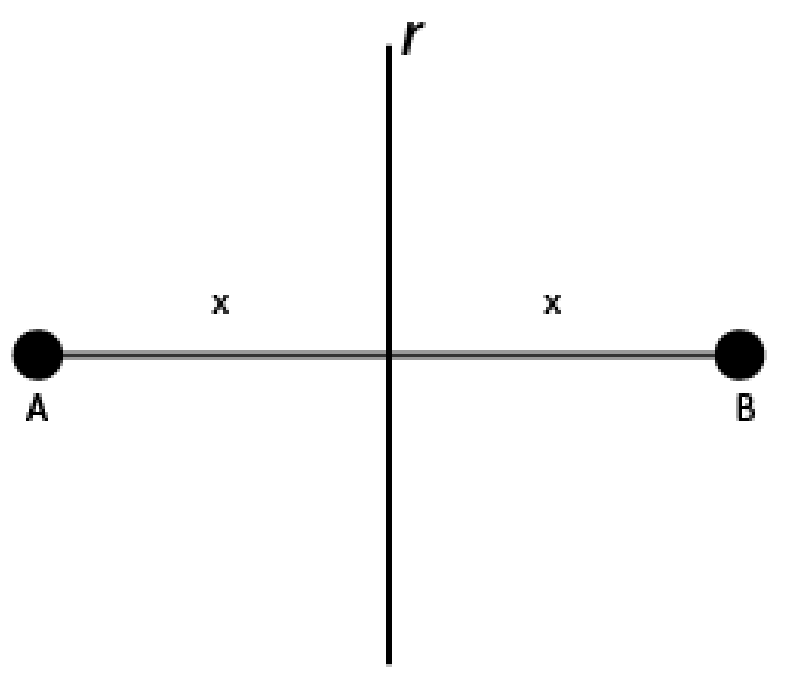

Fonte: Próprio autor

Figura 7 - Simetria de Reflexão

(3)

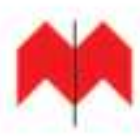

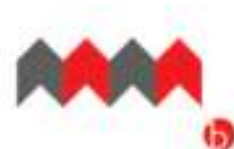
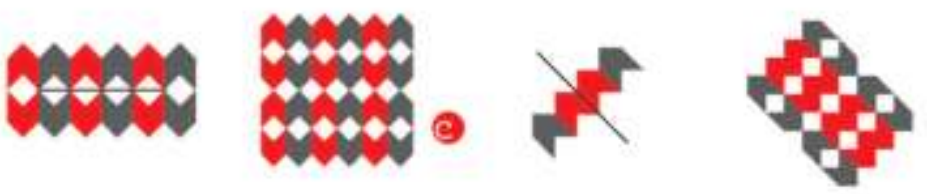

Fonte: Próprio autor.

Outro tipo de simetria é a rotação que se utiliza de um ponto para girar uma figura com um determinado ângulo, Segundo Barbosa (2010), este ponto é chamado de Centro de Rotação ou Rotocentro, já o ângulo é denominado de ‘Ângulo de Rotação'. A Figura 8 apresenta dois centros de rotação, nota-se que o resultado foi diferente em cada uma, na Figura 8.b observa-se um fechamento de um triângulo no centro de rotação, entretanto, na Figura 8.a existe uma junção entre as formas. 
Figura 8 - Exemplos de Rotação.

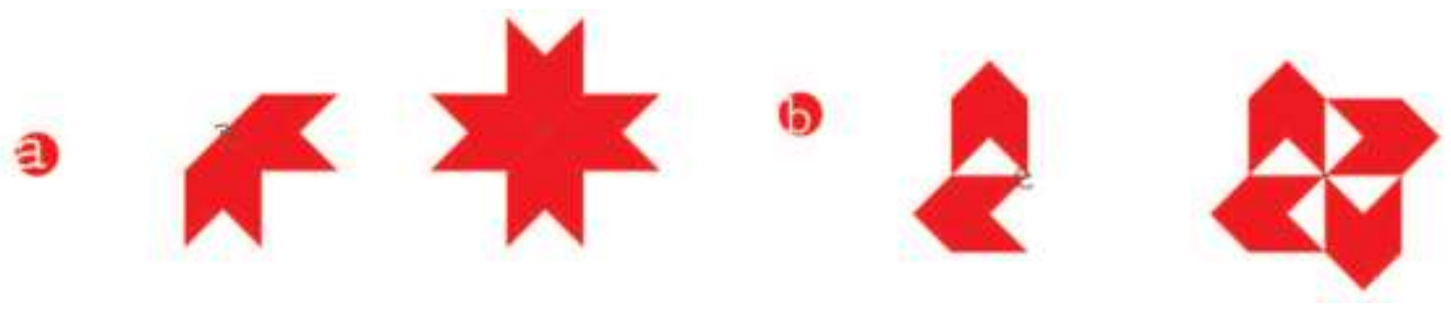

Fonte: Próprio autor.

Translação é outro tipo de simetria, em que a figura é disposta no plano a uma mesma distância gerando um padrão (DOREEN et al., 2012). A Figura 9 demonstra que a forma vermelha é disposta em intervalos regulares. Cale ressaltar que a distância pode ser 0, isto é, a repetição pode se manter lado a lado (JABLAN, 1995).

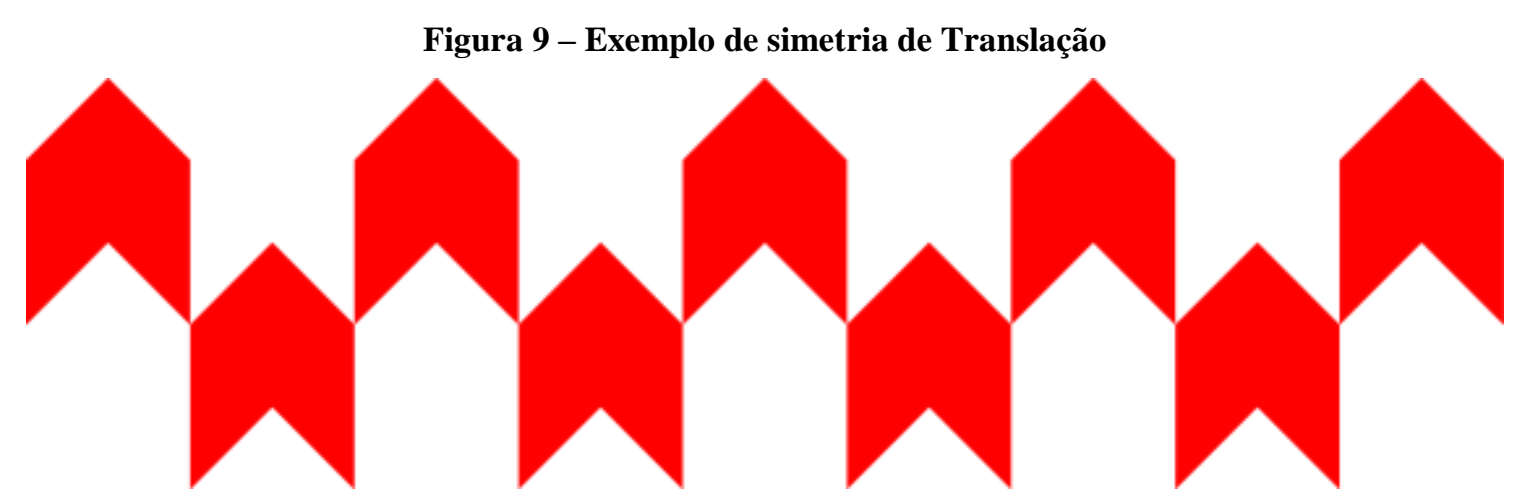

Fonte: Próprio autor

Existe também a simetria de 'Grade de Reflexão"1 em que, segundo de Jablan (1995) e Doreen et al. (2012), ocorre a partir de uma junção com dois tipos de simetria [translação \& reflexão] a Figura 10 demonstra o processo. A princípio o módulo é repetido seguindo um eixo na horizontal [trabalhando a simetria de translação] depois é traçado um eixo de simetria para realizar a reflexão dos módulos. Contudo, Barbosa (2010) intitula esta simetria como 'Translacional Refletida' definindo: “[...] é o que se costuma chamar de produto de duas transformações (duas simetrias). Observamos, no

\footnotetext{
${ }^{1}$ Sendo o termo original Glide reflection, encontrado nos trabalhos de Jablan (1995), com uma tradução livre.
} 
entanto, que esse produto é comitativo, pois podemos trocar a ordem.” (p. 48). Desta forma, esses autores conceituam esta simetria da mesma maneira, porém, com nomenclaturas distintas.

Figura 10 - Exemplo de simetria de Grade de Reflexão.
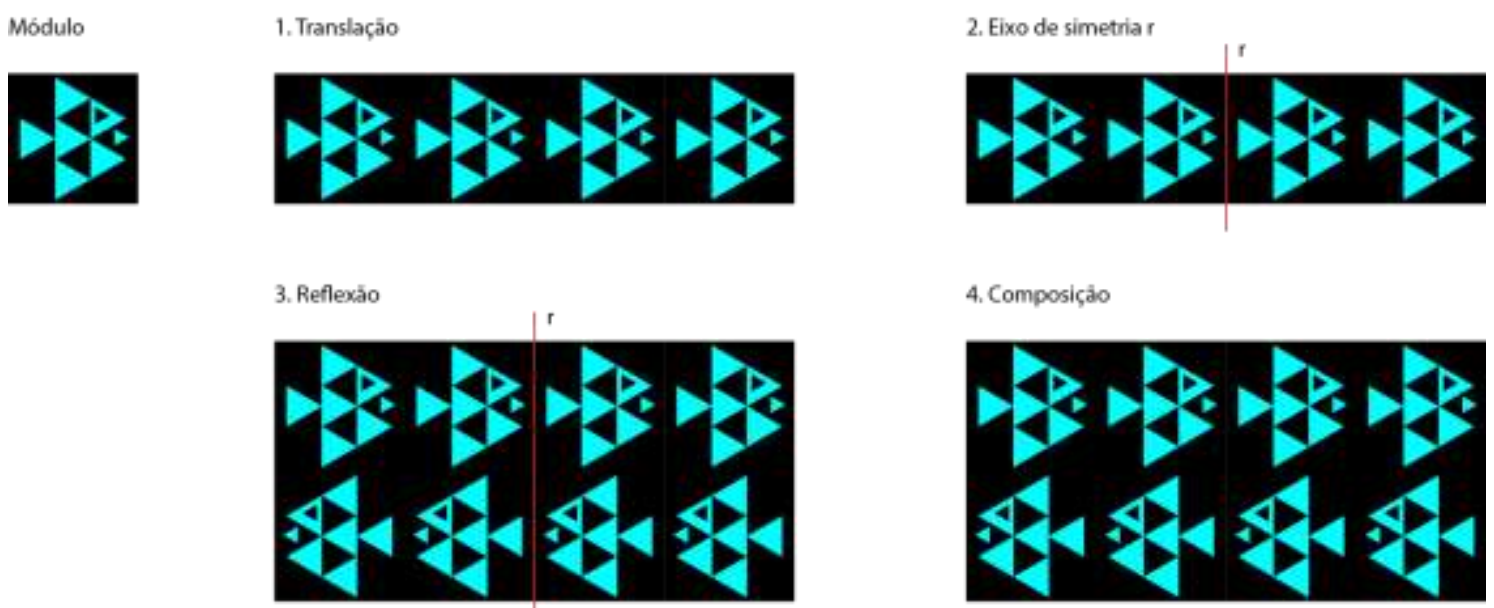

Fonte: Próprio autor.

\section{Processo de configuração de Design de Superfície}

Este processo passa pelas seguintes fases: Escolha do tema; Elaboração dos Elementos/Motivos juntamente com a escolha das Cores; Construção do Módulo; Geração de alternativas [Repetição]; Escolha das alternativas.

Para a configuração de uma estampa existe a necessidade de um tema, pois é a partir deste que o designer ou ilustrador buscará elementos/motivos, cores, estruturas, com o intuito de compor uma unidade visual para o seu projeto gráfico. Isto é, a temática é a base do projeto de superfície para que o designer ou ilustrador crie grafismos representativos e/ou abstratos para a composição com o objetivo de gerar uma linguagem.

A Figura 11 contém quatro estampas com temas diferentes: na primeira foi trabalhado com motivos florais [natureza] e apresenta uma paleta de cores suaves com tons pastel criando uma composição sutil e delicada; na segunda foi articulado motivos, referente à cultura oriental, as tradicionais Kokeshi ${ }^{2}$ [bonecas de decoração] e as cores

\footnotetext{
2 Mais informações em: < http://www.japaoemfoco.com/kokeshi-dolls-as-bonecas-tradicionaisjaponesas/> Acesso em: 20 de maio de 2015.
} 
aplicadas foram de tons vibrantes [principalmente o vermelho e amarelo] trabalhando bem os contrastes; na terceira foi trabalhado com elementos referentes à hora do Chá das Cinco e apresenta cores contraste e formas delicadas; na quarta foi trabalhado o tema a região da Tunísia em que seus elementos apresentam uma conexão com a cultura islâmica e a sua paleta de cores são de caráter natural que tiveram como base imagens do cenário desta região. Nota-se que a escolha da temática é relevante para o processo de criação, pois o designer ou ilustrador vai se apropriando dos signos, códigos [linguagem visual] que caracterizam o tema, para assim, representar, da melhor maneira os motivos/elementos.

Figura 11 - Exemplos de Estampas.
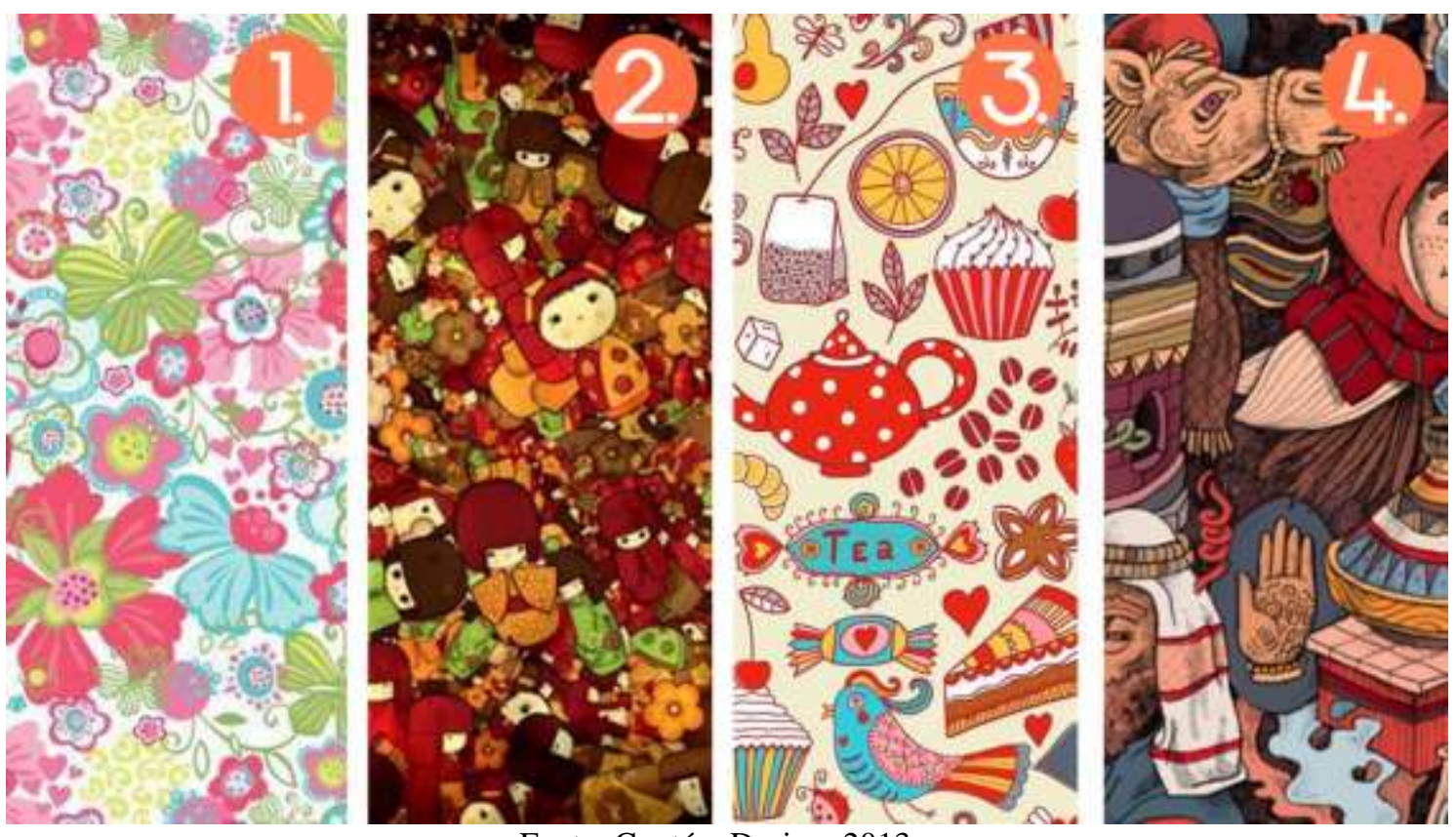

Fonte: Contém Design, 2013c.

Definido o tema o designer/ilustrador deve buscar referências de elementos que tenham relação com a temática. Esta fase é marcada pela a construção dos 
desenhos/formas que faram parte da composição da estampa. A imagem [desenho ou fotografias] pode ser obtida por meio de manipulação digital [utilizando de programas, computação gráfica] ou desenho manual. Isto é, as figuras criadas para a composição tem a viabilidade de serem criadas com materiais físicos como lápis [por exemplo, grafite e aquarela], tinta, papéis, moldes de madeira ou stencil, entre outros e gerar uma composição [Figura 12]. De maneira que existe a possibilidade de elaborar um desenho a mão livre depois fotografar ou escanear, para assim, editar no Photoshop - por exemplo. 
Figura 12 - Estampa criada de modo manual.

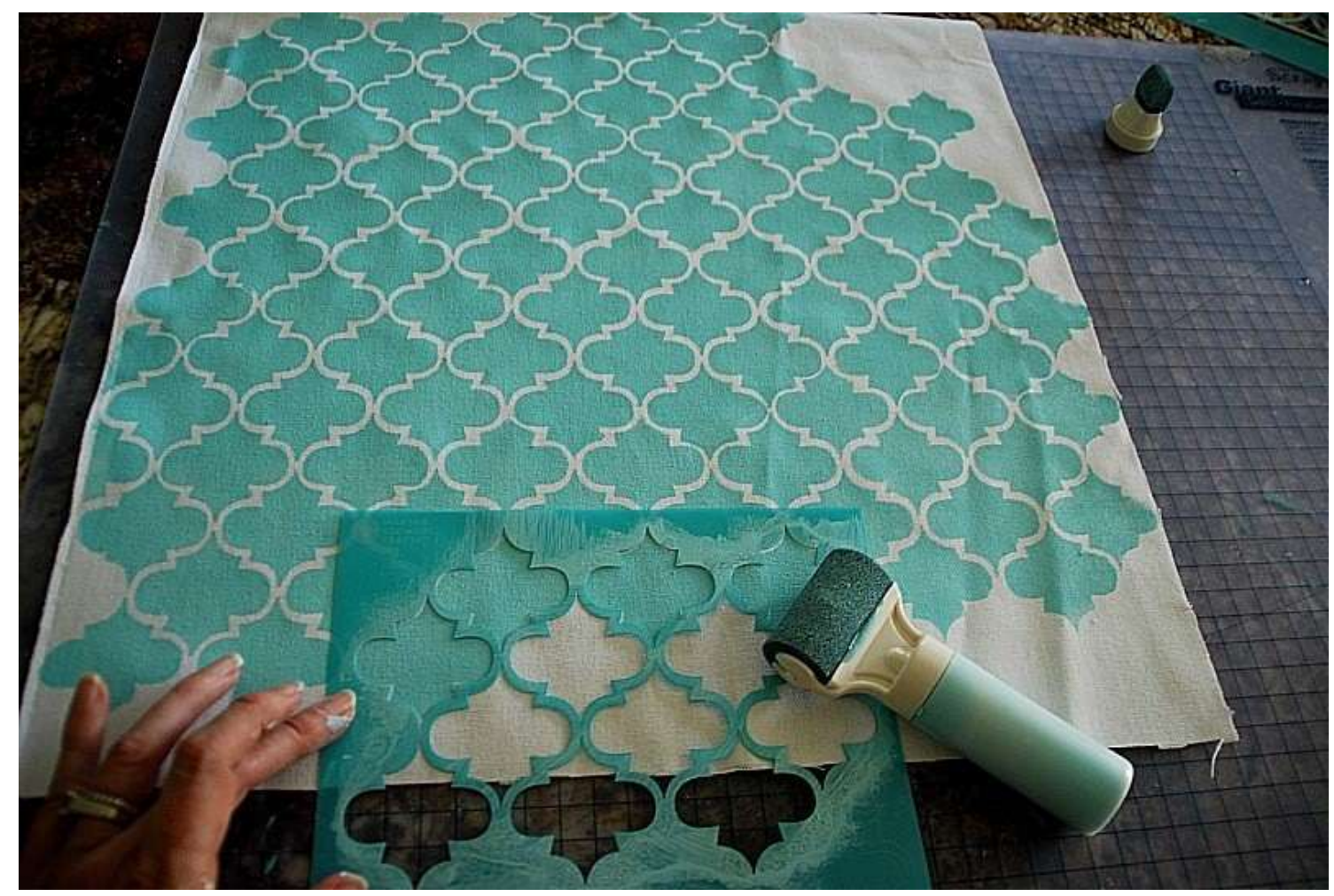

Fonte: Contém Design, 2013c.

Nota-se que os mecanismos são diversos para criar as formas, contudo Wong (2010) divide a forma em dois tipos:

- Figurativa são as formas que detêm um significado para o observado e podem ser representadas de modo realístico ou com certo nível de síntese com o objetivo construir um desenho que seja reconhecido pelo observador. As figurativas ainda podem ser subdividas de acordo com a temática: Formas Naturais [elementos com interligados com a natureza]; Formas Feitas pelo Homem [elementos referentes aos artefatos, construções, espaços criados pelos seres humanos]; Formas Verbais [seriam as letras, textos, caracteres, elementos relacionados à tipografia/escrita].

- Não figurativa [abstrata] contempla formas que não representam um tema reconhecível pelos sujeitos.

As formas podem ser representadas demonstrando todas as características ou apenas algumas, ou ainda tendo uma fuga total [abstrata]. Para entender esta fase de construção 
dos elementos bem como as seguintes do processo de criação das estampas optou-se pela temática Game apresentando o jogo Super Mario [Figura 13] como referência.

Figura 13 - Super Mario.

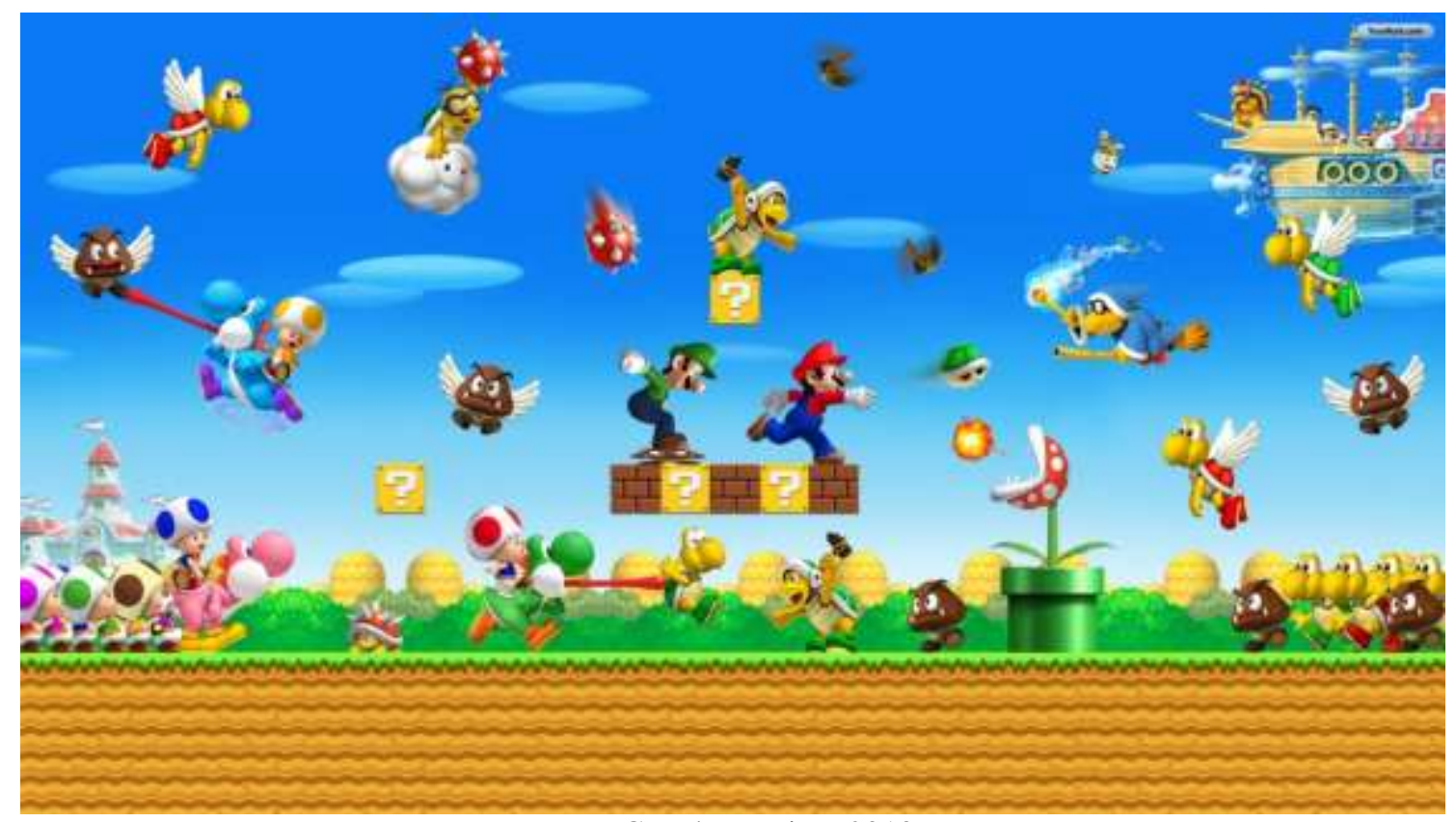

Fonte: Contém Design, 2013a.

Com isso, realizou-se uma pesquisa de imagens, ilustrações, artefatos relacionados a este jogo. O objetivo desta busca foi de ter um referencial visual sobre o universo do game e os seus elementos mais significativos, sendo analisadas mais de 100 imagens. Percebeu-se que as imagens do Mário [personagem principal], estrela, interrogação e cogumelos eram elementos mais recorrentes nas representações. As imagens abaixo [Figuras 14 e 15] ilustram os motivos criados a partir das referências juntamente com a paleta de cores extraída a partir das imagens, nota-se que os elementos foram construídos a partir de formas básicas. Por exemplo, para caracterizar o personagem Mário foi elaborado um desenho sem muitos detalhes, ou seja, formas simples contendo aspectos essenciais.

Cabe ressaltar que os elementos foram gerados por meios digitais utilizando o programa Illustrator. Cada elemento foi configurado com o estilo da autora, assim, contendo traços simples e formas planas, buscando não descaracterizar os motivos em relação ao original. Assim, a elaboração dos elementos depende do estilo e/ou técnica 
de desenho de cada ilustrador/designer, e, também, do modo que vai ser construído [manual e/ou digital].

Figura 14 - Referências, Elementos e Paleta de Cores.

\section{Referência}
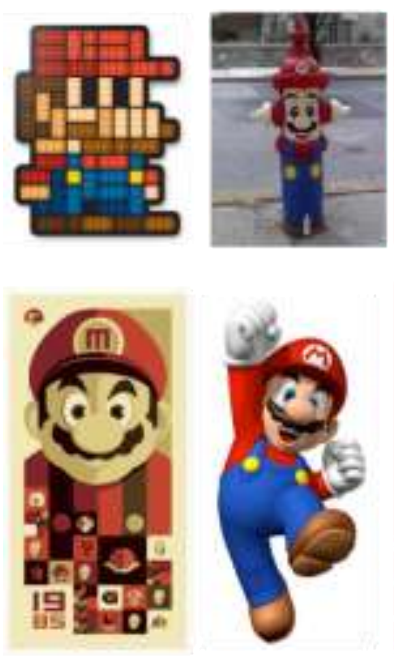
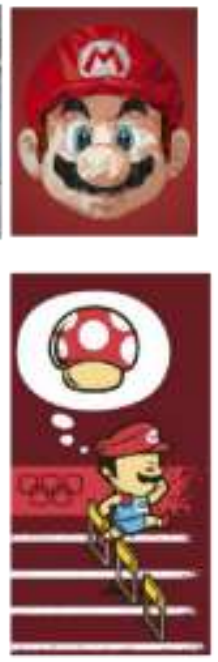

\section{Elementos}
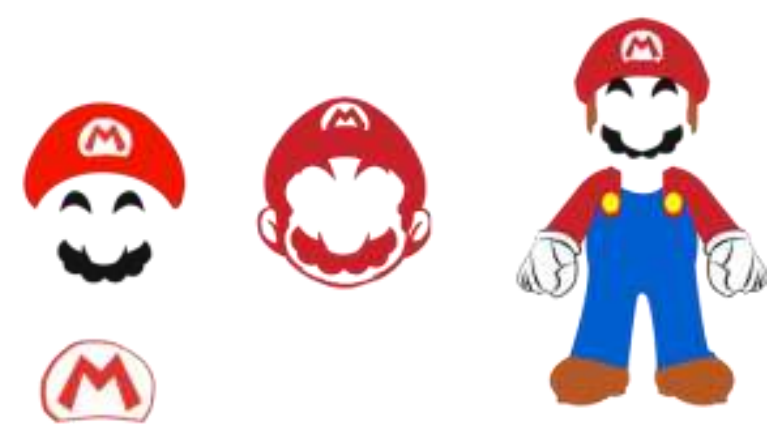

Cores
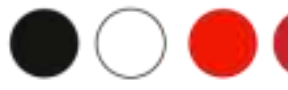

Fonte: Próprio autor. 
Figura 15 - Referências, Elementos e Paleta de Cores.

\section{Referência}

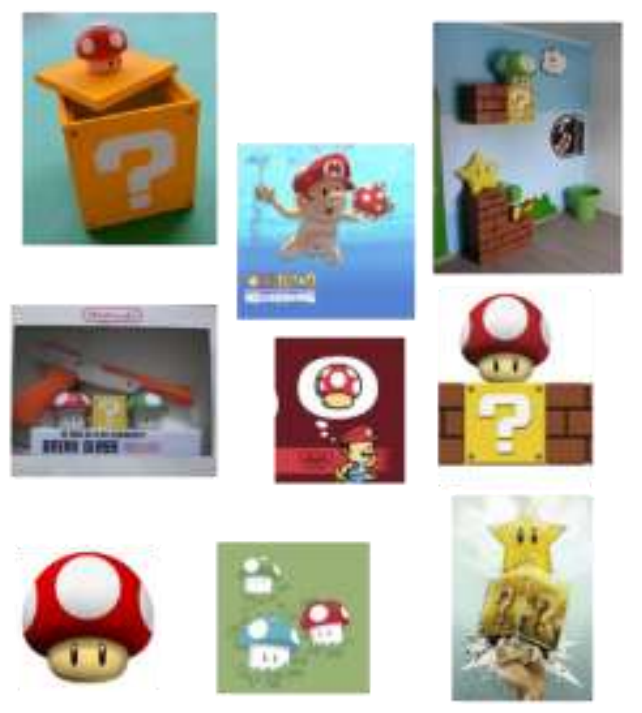

\section{Elementos}

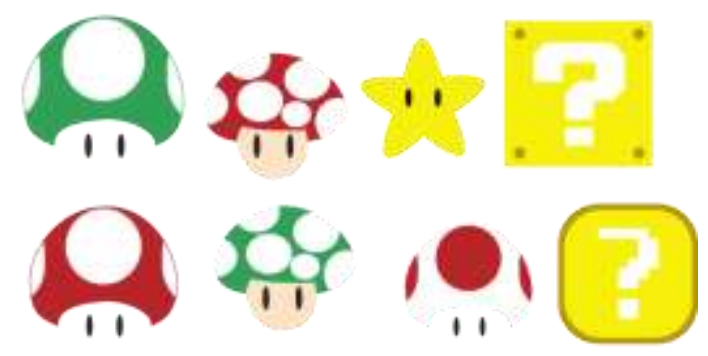

Cores

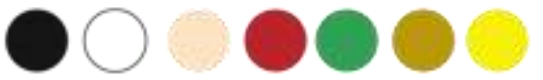

Fonte: Próprio autor.

Tendo elaborado os elementos básicos para compor a estampa é chegada à etapa de Construção do Módulo que como visto anteriormente pode ser trabalhado com uma figura geométrica. Optou-se por trabalhar com as seguintes formas: quadriláteros; hexágonos e triângulos. Contudo, a simetria também é um fator fundamental nesta construção, pois, é ela que 'orienta' o módulo durante a repetição. A Figura 16 apresenta um módulo triangular sem encaixe em que neste foi aplicado três tipos de simetria diferentes [Rotação, Reflexão, Translação], desta forma, a repetição gera uma composição diferente como pode ser observado nesta Figura 16. 
Figura 16 - Módulo triangular com diferentes tipos de simetria Módulo Simetria de Rotação Simetria de Reflexão Simetria de Reflexão
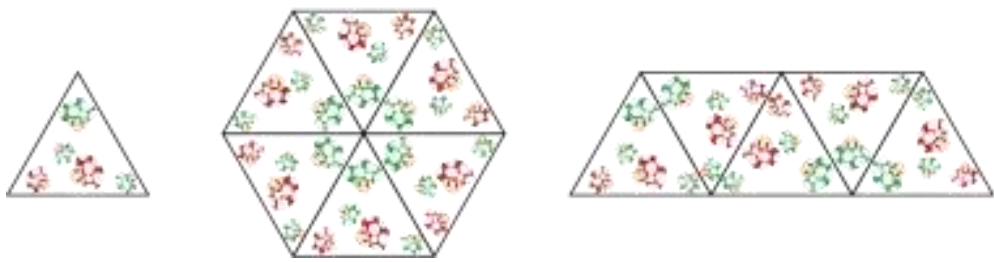

Fonte: Próprio autor.

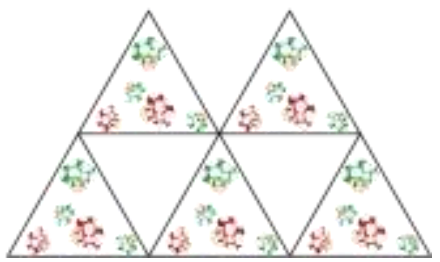

Para a construção do módulo pode ser levado em consideração os encaixes, ou melhor, pensar nas laterais com o objetivo de gerar continuidade. Este aspecto é de grande importância, pois, caso o designer/ilustrador não trabalhe corretamente os encaixes do módulo isso gera erros. A Figura 17 demonstra que quando o encaixe é mal elaborado ocorrendo falhas na continuidade dos elementos, na ampliação de número 1 os cogumelos apresentam uma distorção [deslize] gerando uma quebra da continuidade. Já na segunda ampliação, é observada a falta de sequência das partes do cogumelo verde, ou melhor, existe uma omissão das formas do cogumelo. 
Figura 17 - Estrutura de um Módulo com encaixe incorreto

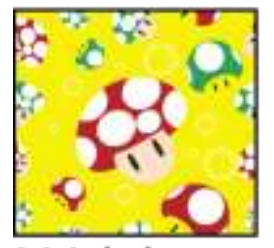

Módulo com contorno

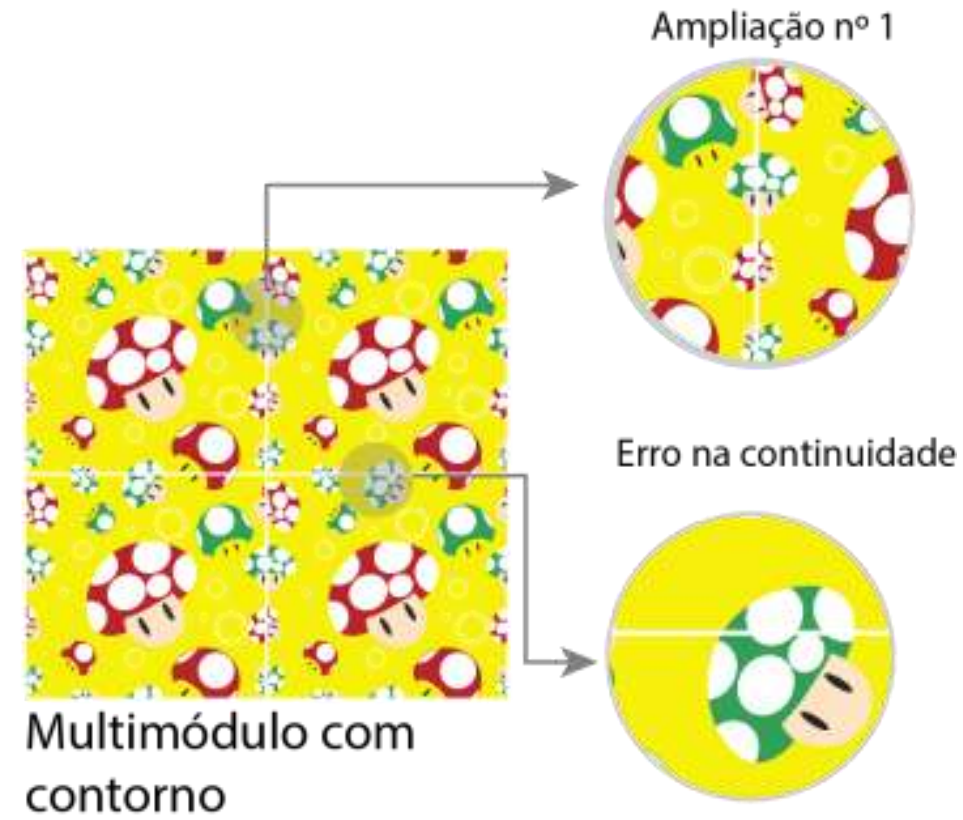

Ampliação $n^{\circ} 2$

Fonte: Próprio autor.

Com isso, existe a necessidade de saber corretamente as técnicas, para assim, construir o módulo. As imagens a seguir são representações de um passo a passo para configurar os módulos com o auxílio da simetria. Para a construção dos módulos foram utilizados os elementos básicos da temática [Figuras 14 e15] e também outros grafismos circulares. O módulo A teve como técnica aplicada o Rapport Direto. Esta técnica consiste que os elementos aplicados nas laterais [vertical e/ou horizontal] devem coincidir com as suas opostas/paralelas, ou seja, os elementos colocados na lateral esquerda precisam ser reproduzidos fielmente na lateral direita, do mesmo modo os elementos contidos no lado superior devem ser replicados para o lado inferior. Desta forma, o Rapport Direto trabalha com a simetria de translação [Figura 9]. Na Figura 18 os elementos não sofrem nenhum deslize ou omissão, assim, existe a uma continuidade, outro fator a ser observado é a não utilização de contornos nas extremidades do quadrado, pois, dependendo da espessura da linha ['outiline'] poderiam gerar quebras na continuidade dos elementos [Figura 19]. 
Figura 18 - Passo a Passo da construção do Módulo A com a técnica Rapport Direto.

\section{Módulo A | Com o encaixe}

\section{Rapport Direto \\ com quadrado}

01

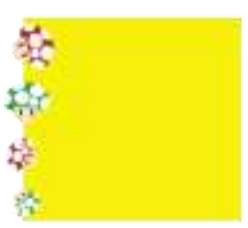

Copie os elementos da lateral esquerda para sua lateral oposta. De modo que eles devem coincidir lestar no mesmo ponto que a outra lateral].

04

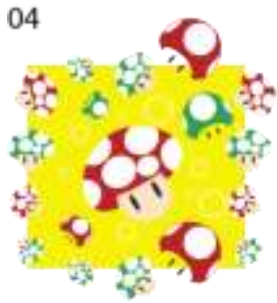

Acrescente elementos no interior do quadrado. Acrescente elementos no interior do quadrado.

Fonte: Próprio autor.

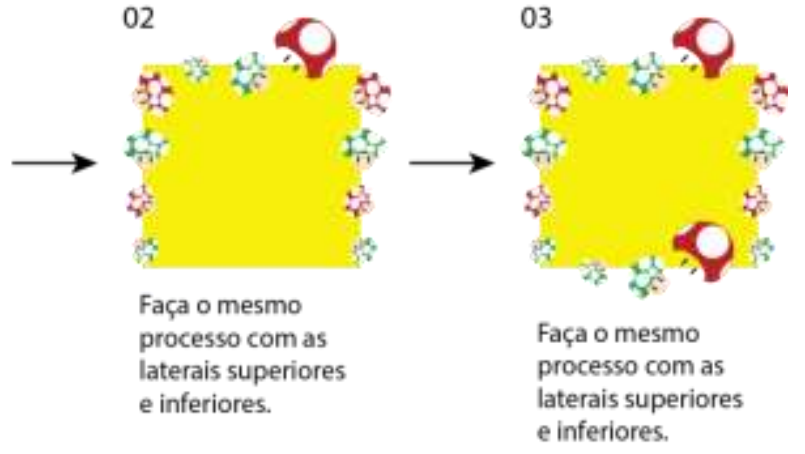

05

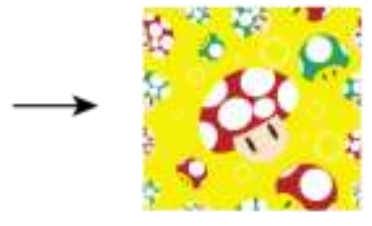

Depois faça um recorte eliminando os elementos da parte externa do quadrado.

Figura 19 - Módulo A com contorno.

\section{Módulo com o encaixe incorreto}

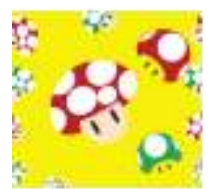

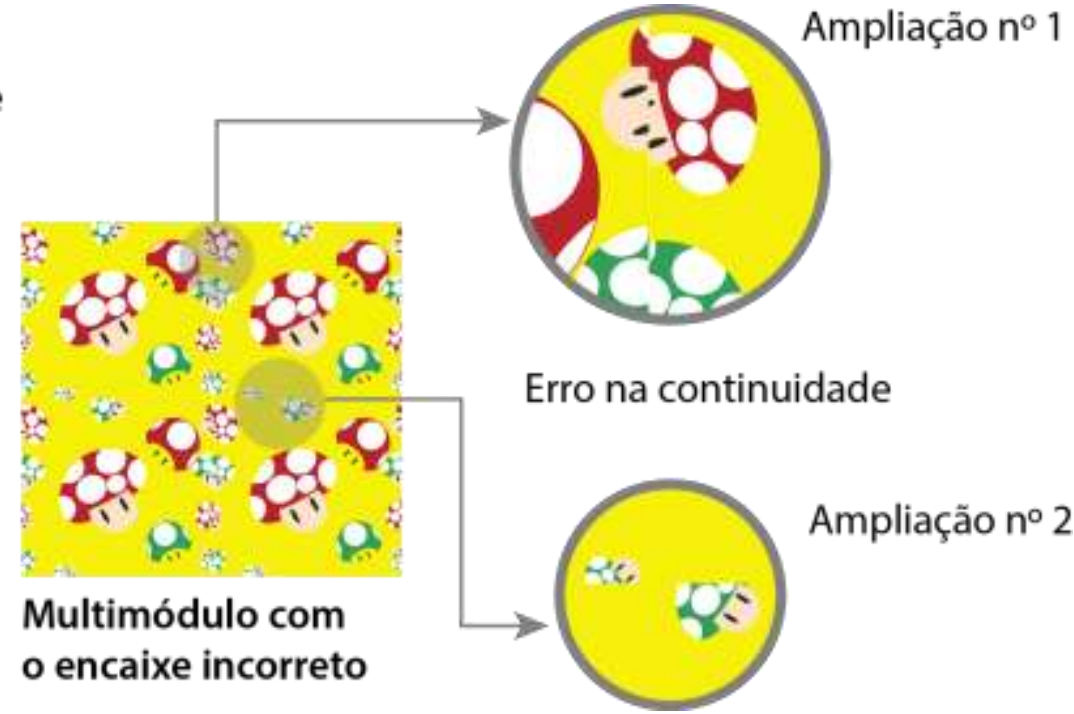

Fonte: Próprio autor. 
Já o módulo B a figura geométrica utilizada foi o triângulo em conjunto com a simetria de Rotação para dispor os elementos. A técnica com essa figura é similar com a do Rapport Rotativo que Suono, Berton e Pires (2013) definem este rapport como uma técnica que "[...] utiliza um sistema de encaixe feito por meio de linhas perpendiculares entre si e que partem do mesmo ponto de origem" (p.8), neste caso os autores tem o quadrado como forma base para repetir os elementos. A Figura 20 ilustra como o encaixe é realizado, assim, os elementos que estão no vértice 1 devem coincidir com o vértice 1 '.

Figura 20 - Rapport Rotativo (Simétrico) e Sistema de Distribuição dos Módulos.
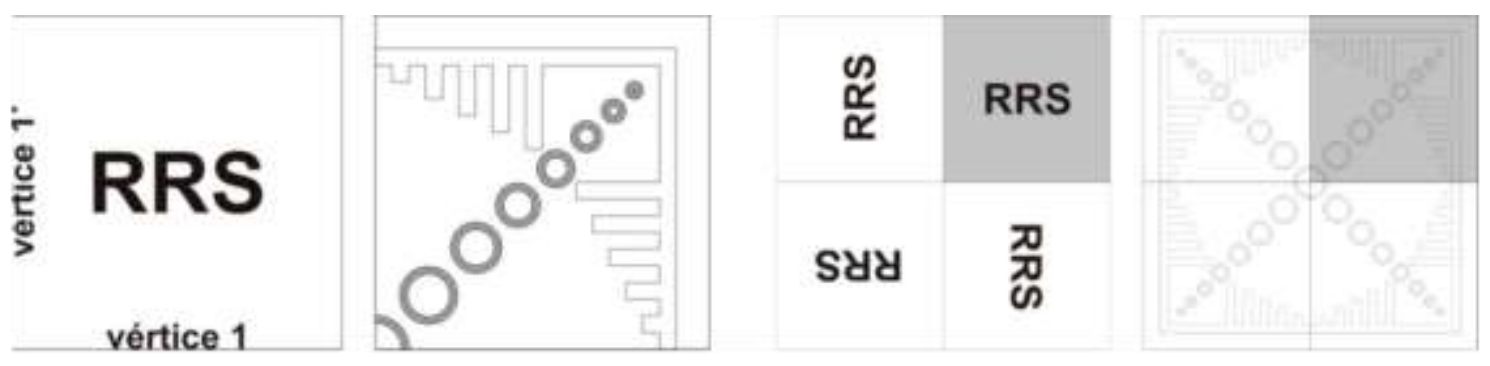

Fonte: SUONO, BERTON, PIRES, 2013, p. 10.

Desta forma, a técnica de Rapport com o triângulo equilátero funciona da seguinte forma os elementos que estão do lado esquerdo são rotacionados para o lado direito do polígono - como ilustra a Figura 21. A base do triângulo equilátero é divida em duas partes para que os elementos colocados neste lado tenham continuidade, pois, conforme se repete o módulo à base do triângulo se inverte [Figura 22].

Figura 21- Passo a Passo da construção do Módulo B com a técnica Rapport com o triângulo equilátero.

\section{Módulo B | Com o encaixe}

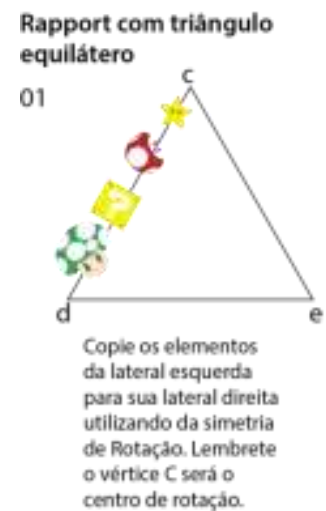

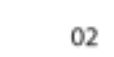

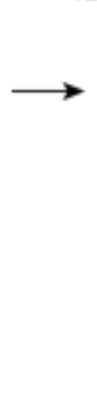

02

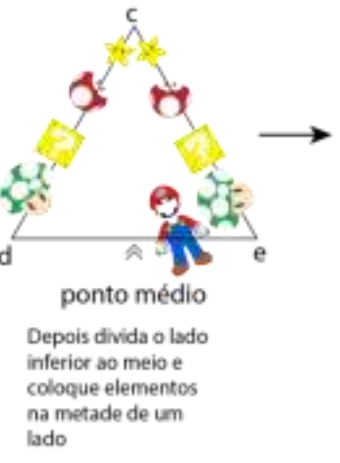

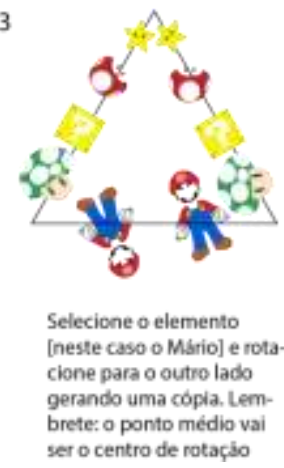

04

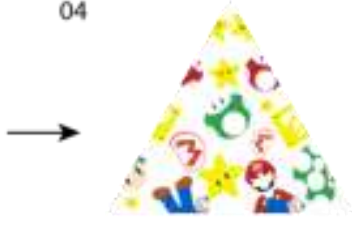

Depois coloque elementos no interior do triasngulo $\mathrm{e}$ eliminando as partes extemas do triangulo. Lembre de tirar o contorno,

Fonte: Próprio autor. 
Figura 22 - Repetição do Módulo B.
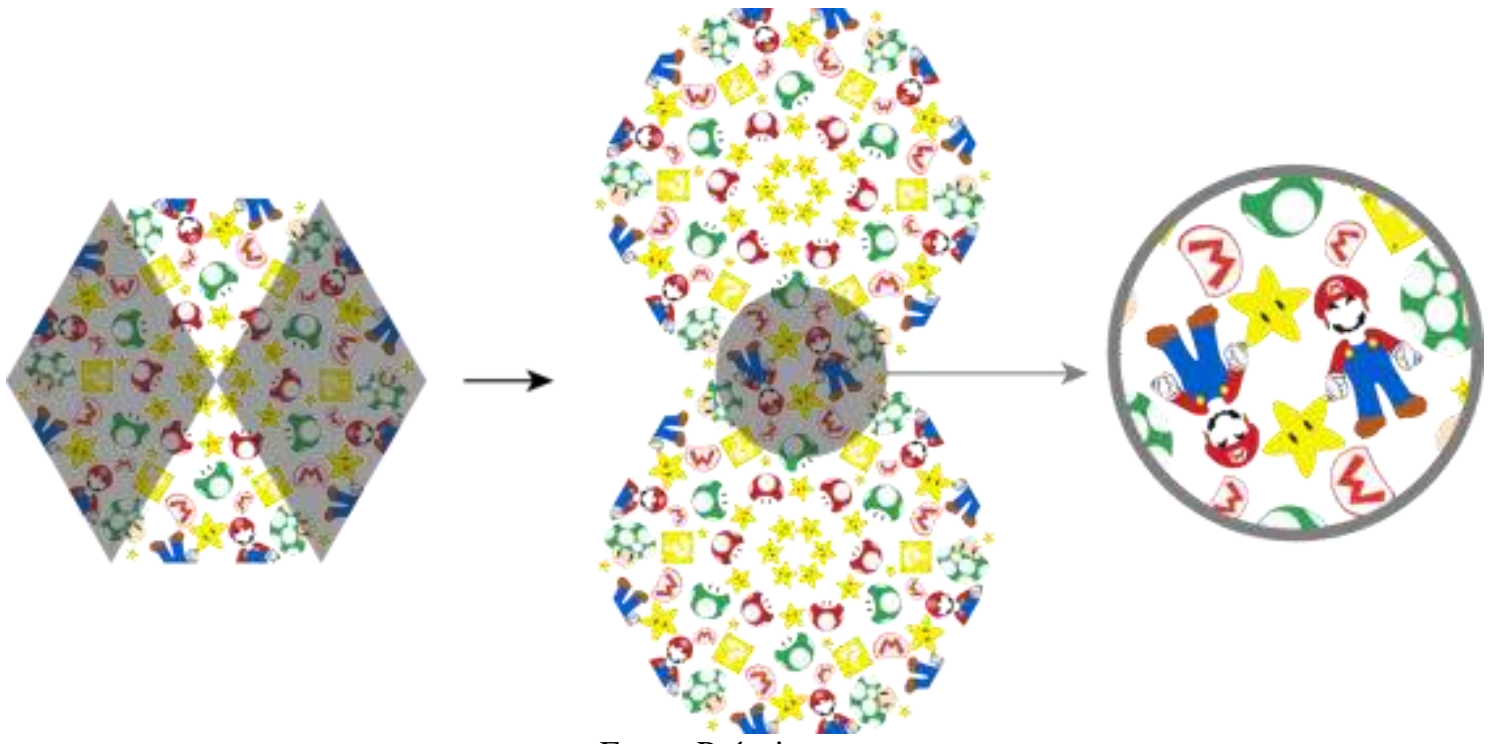

Fonte: Próprio autor.

A construção do módulo C tem como base a técnica Rapport Direto, entretanto, utilizando do hexágono para comportar os elementos. Assim, os elementos dispostos nas laterais devem ser replicados para os respectivos lados opostos, a Figura 23 ilustra o passo a passo da construção do módulo C.

Figura 23 - Passo a Passo da construção do Módulo C com a técnica Rapport Direto com

\section{Hexágono regular.}

\section{Módulo C | Com encaixe}

\section{Rapport Direto com \\ hexágono regular}

01

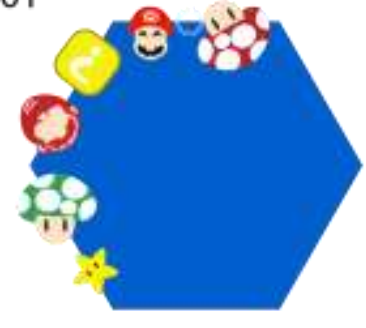

Copie os elementos de cada lateral para os respectivos lados opostos.

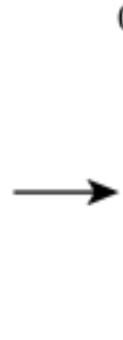

02

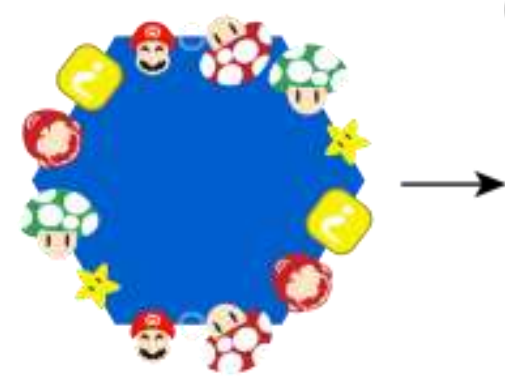

Copie os elementos de cada lateral para os respectivos lados opostos.
03

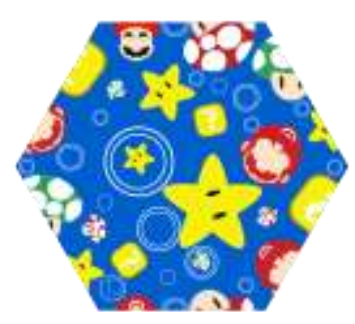

Depois coloque elementos no interior do hexágono e eliminando as partes externas do hexágono

Fonte: Próprio autor. 
O módulo D teve como base a técnica do Rapport Direto, entretanto, o polígono base utilizado foi o losango. A Figura 24 apresenta o passo a passo dessa construção. Neste caso o elemento interrogação como está localizado em um dos vértices do losango ele será reproduzido em todos os outros da figura.

Figura 24 - Passo a Passo da construção do Módulo C com a técnica Rapport Direto com Losango regular

\section{Módulo D | Com encaixe}

\section{Rapport Direto com losango regular}

01

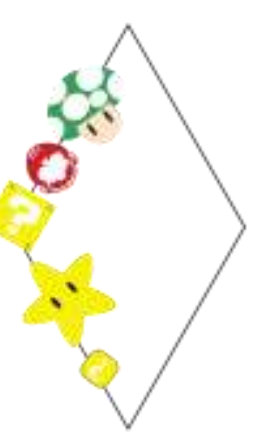

Copie os elementos de cada lateral para os respectivos lados opostos.

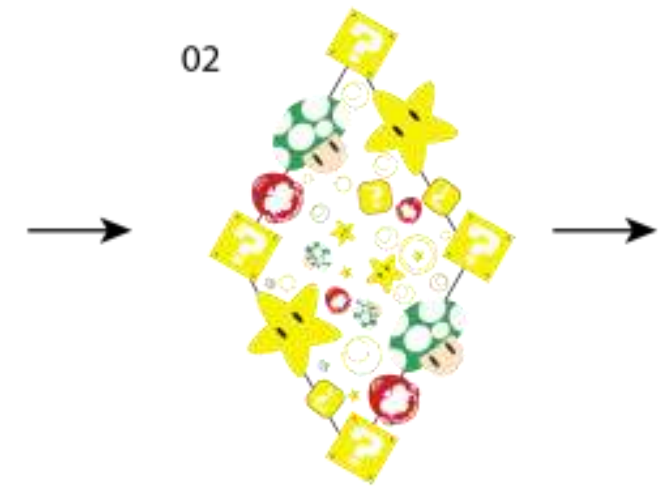

Depois coloque elementos no interior do losango.

Fonte: Próprio autor.
03

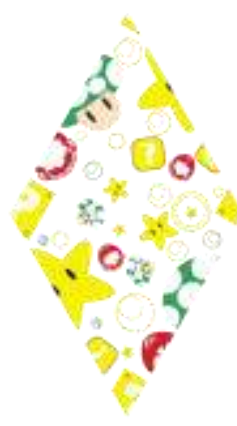

Faça um recorte eliminando as partes externas do losango. Lembre de tirar o contorno.

Para o módulo E foi trabalhado com apenas elementos no interior do retângulo, assim, trata-se de um sem encaixe [Figura 25]. 


\section{Figura 25 - Módulo E. \\ Módulo E | Sem encaixe}

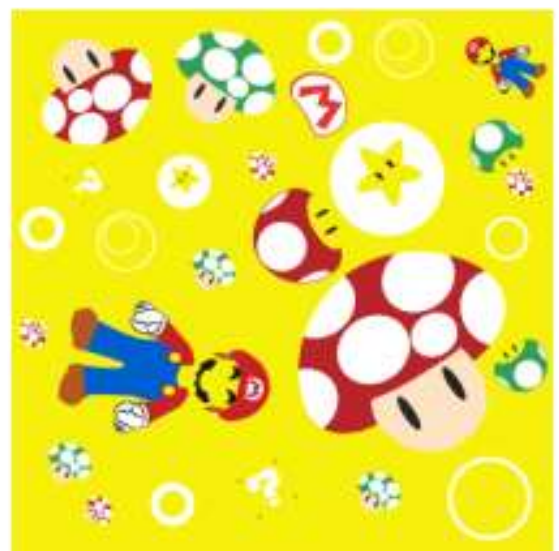

Fonte: Próprio autor.

A próxima etapa corresponde à Geração de Alternativas a partir dos módulos construídos anteriormente, sendo a Figura 26 ilustra o módulo A, a grade de repetição e a estampa. A partir desse módulo foram gerados mais duas versões, com isso, o número de alternativas geradas desse módulo foram 3 [Figura 27]. 
Figura 26 - Módulo A, Grade de Repetição e Estampa.

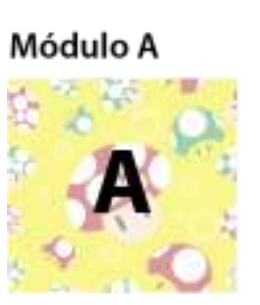

Grade de Repetição

\begin{tabular}{|l|l|l|}
\hline $\mathbf{A}$ & $\mathbf{A}$ & $\mathbf{A}$ \\
\hline $\mathbf{A}$ & $\mathbf{A}$ & $\mathbf{A}$ \\
\hline $\mathbf{A}$ & $\mathbf{A}$ & $\mathbf{A}$ \\
\hline
\end{tabular}

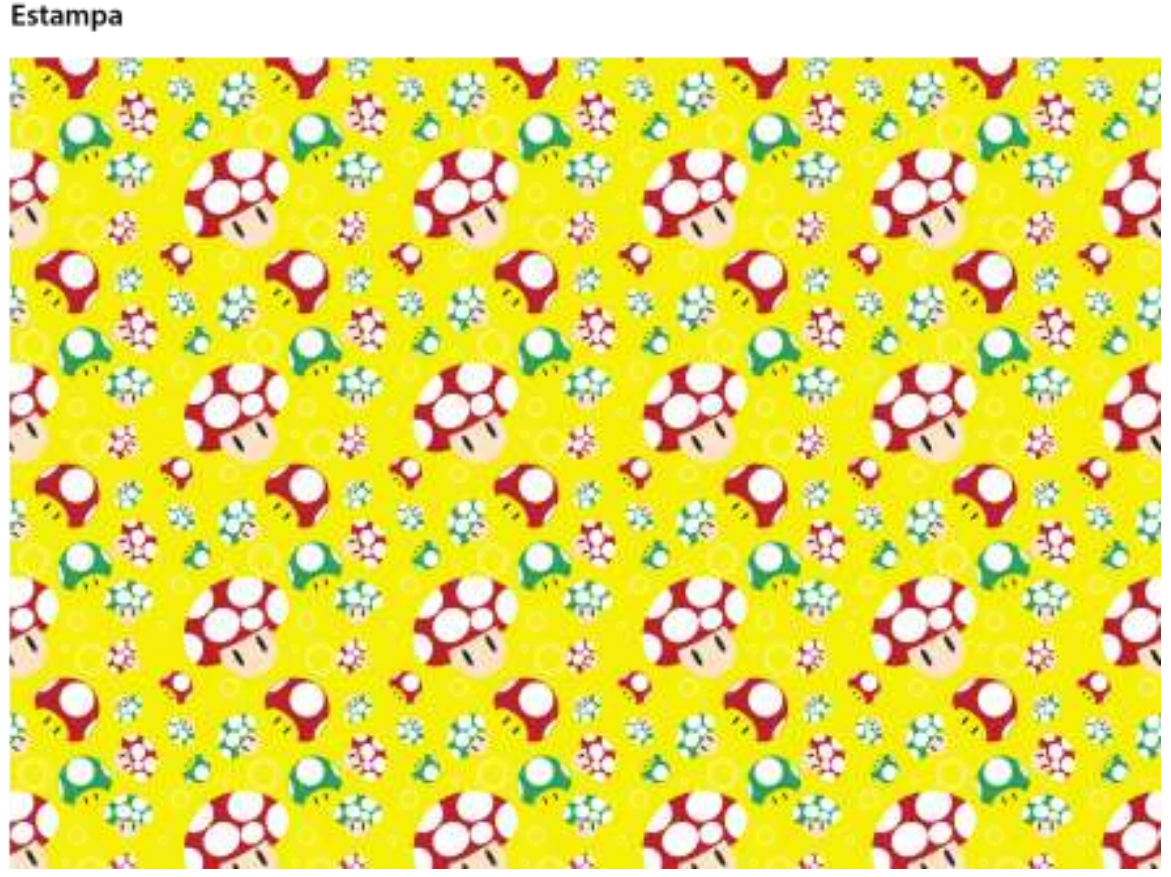

Fonte: Próprio autor.

Figura 27 - Alternativas geradas a partir das versões do Módulo A.

Módulo A | Versóes
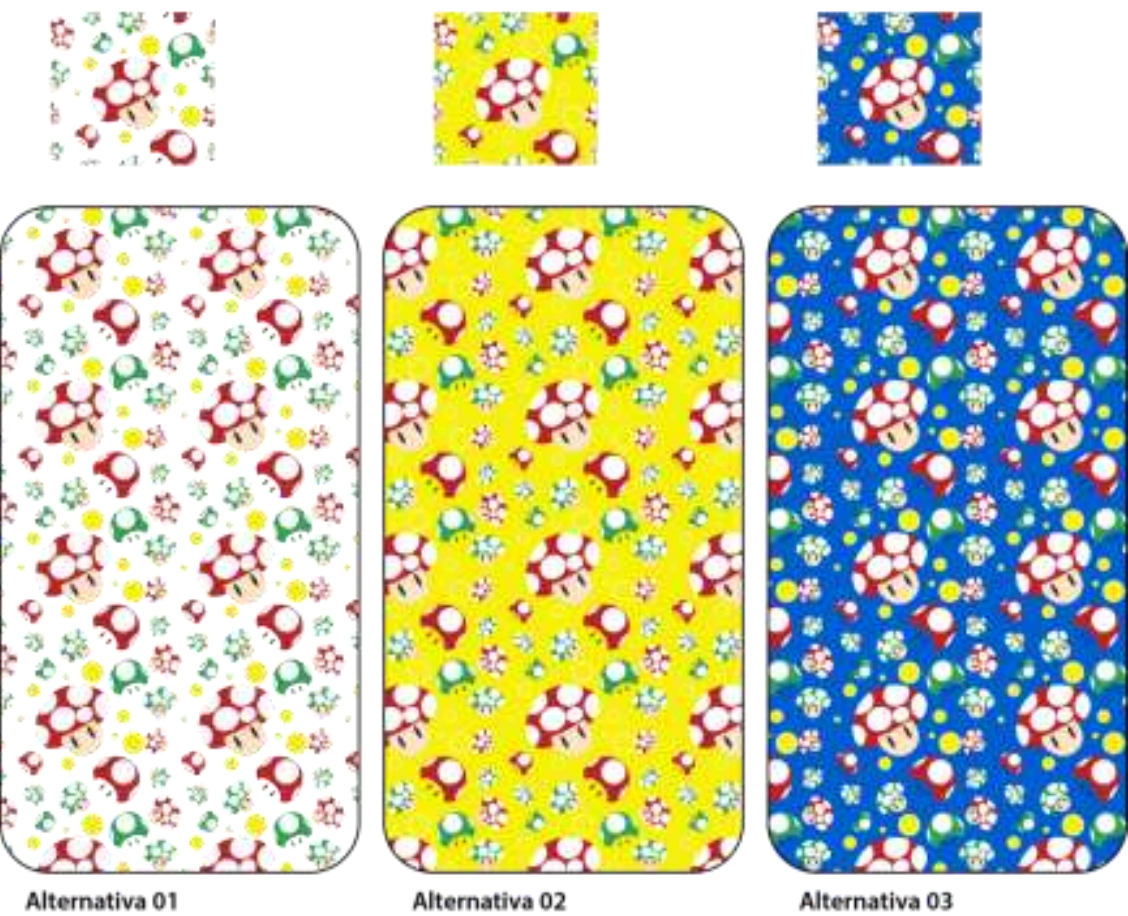

Fonte: Próprio autor. 
O módulo B [triângulo] apresenta uma grade triangular e tem a simetria de rotação como base de repetição do módulo, isso resulta em uma estampa dinâmica [ritmo] em que os elementos são dispostos de um modo menos regular. Diferente do que ocorre na estampa do módulo A que apresentam uma sequência mais igual [parada]. A Figura 29 contempla algumas versões com planos de fundos diferentes em que no primeiro foi aplicado a cor azul e branco e nos demais apenas uma cor.

Figura 28 - Módulo B, Grade de Repetição e Estampa.
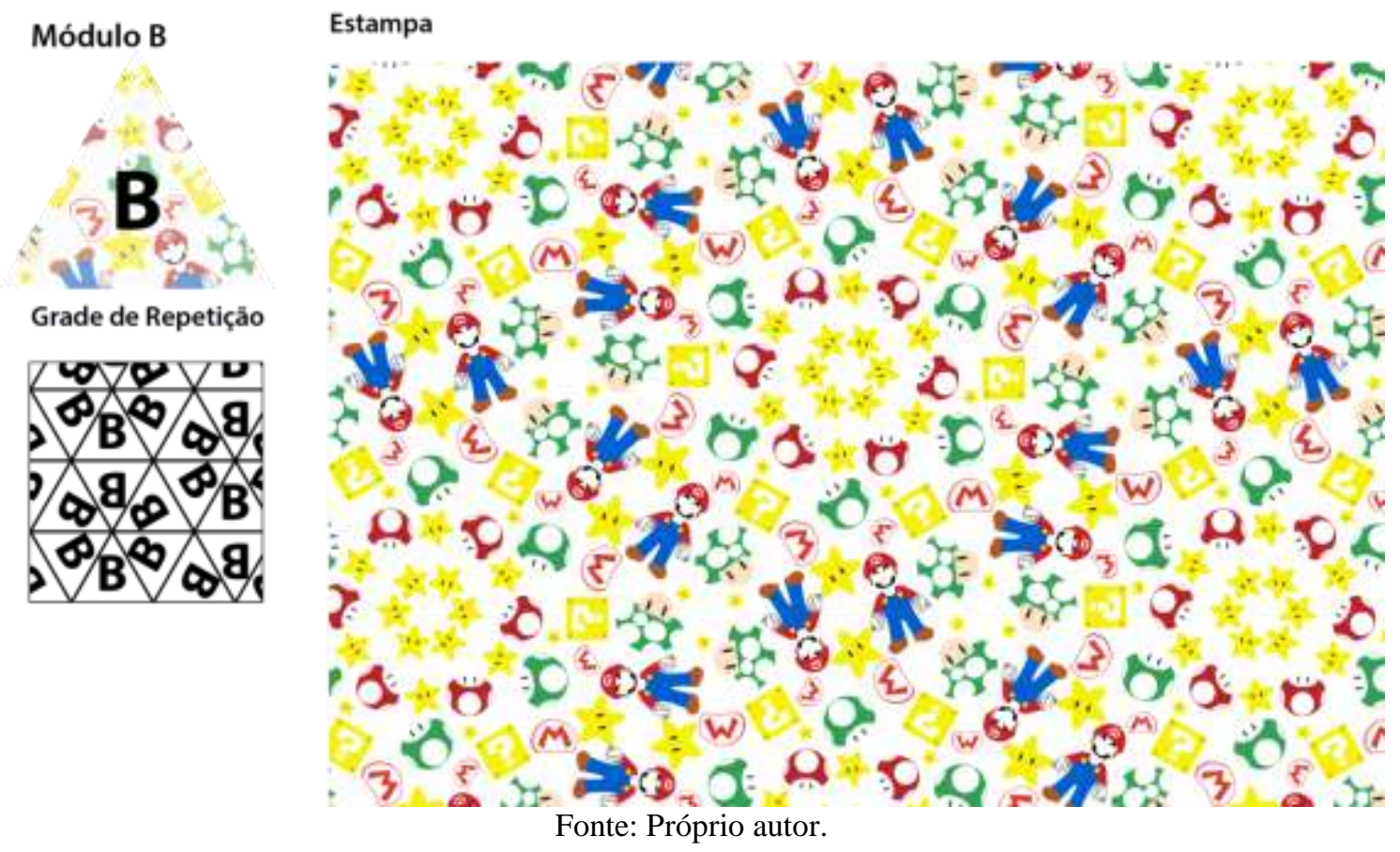
Figura 29 - Alternativas geradas a partir das versões do Módulo B.

\section{Módulo B | Versões}
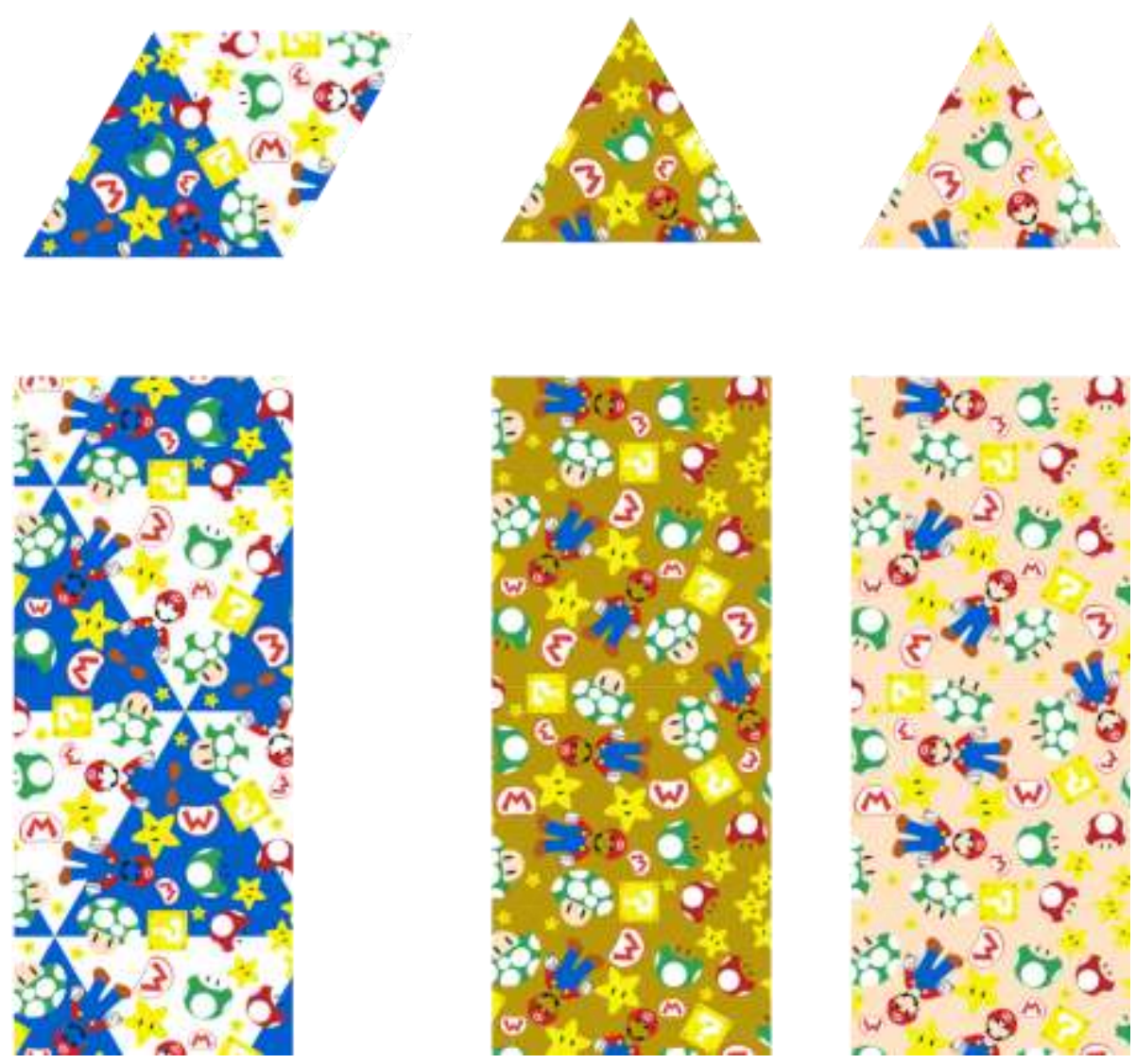

Fonte: Próprio autor. 
A Figura 30 apresenta a grade hexagonal de repetição do módulo $\mathrm{C}$ juntamente com a estampa, percebe-se que também existe um dinamismo maior entre os elementos deste módulo em relação ao A. Isto se deve ao fato que a repetição ocorre utilizando da translação em duas direções diagonal e vertical, enquanto o módulo A segue no sentido de um eixo horizontal e vertical. Para as alternativas do módulo $\mathrm{C}$ foram aplicados planos de fundos diferentes, e, também, um módulo monocromático [Figura 31].

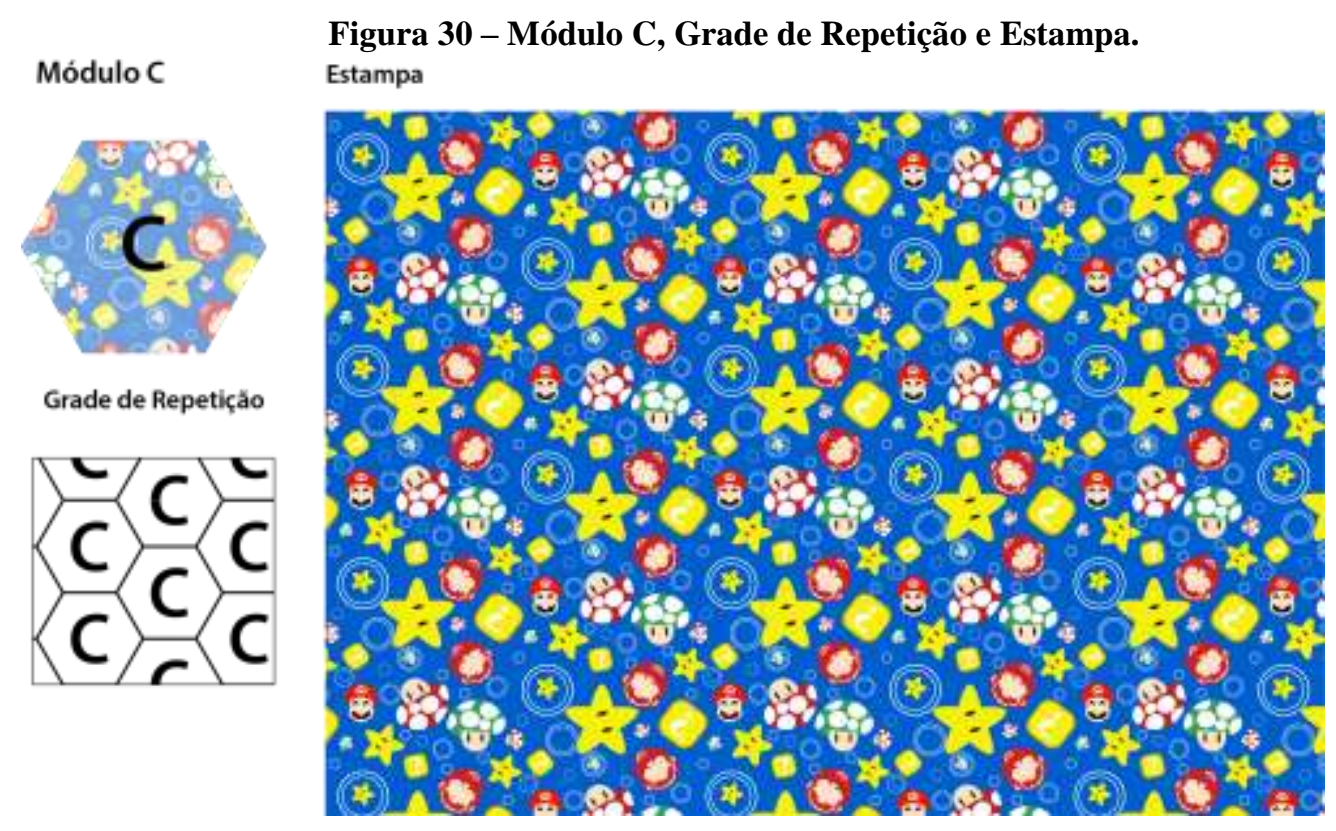

Fonte: Próprio autor. 
Figura 31 - Alternativas geradas a partir das versões do Módulo C

Módulo C | Versōes
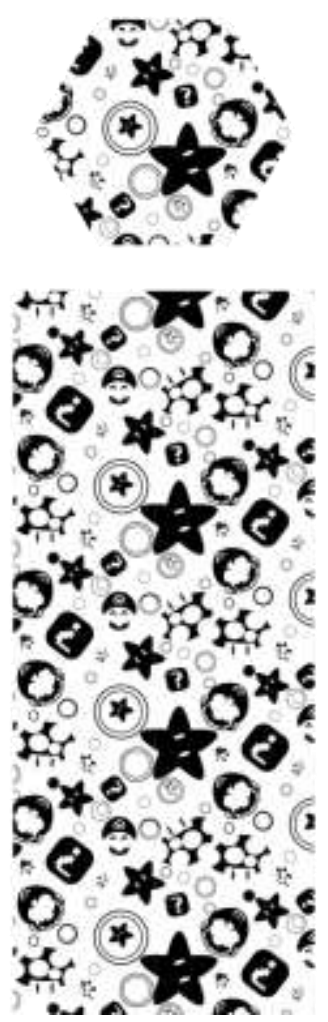
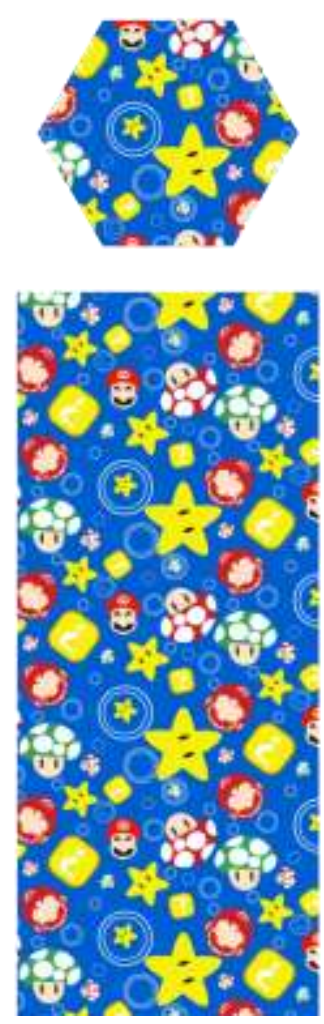
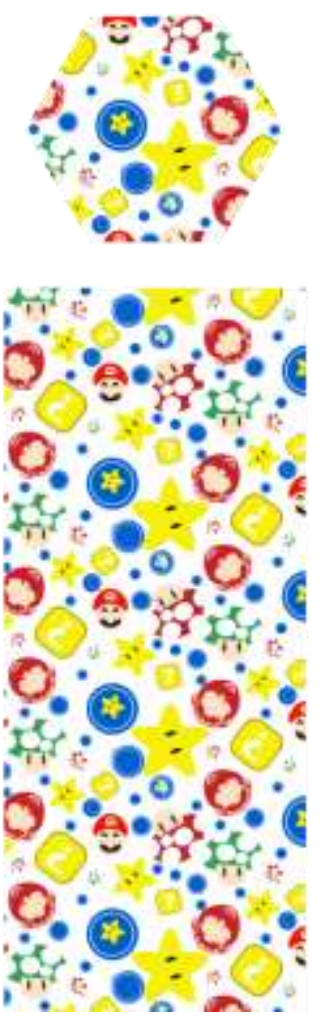
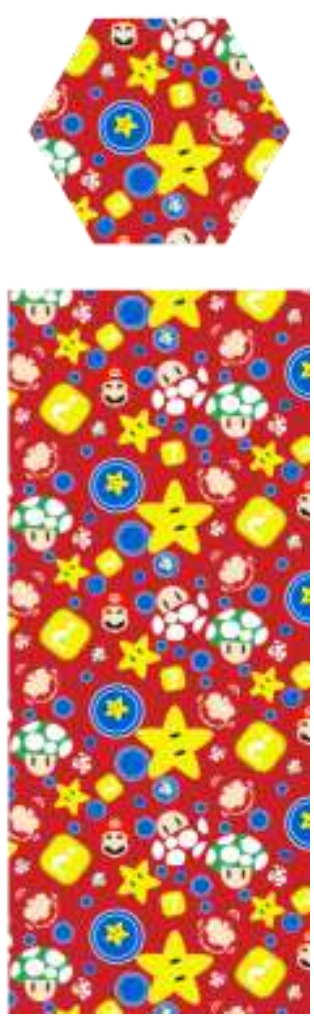

Fonte: Próprio autor.

Com relação ao módulo $\mathrm{D}$, trata-se de uma grade criada a parti do losango como ilustra a Figura 32. Os elementos deste módulo se comportam seguindo um fluxo em diagonal, porém, não apresentam dinamismo equivalente ao B e C, assim, o módulo D se torna similar ao A. Na figura 33 podem ser observadas as alternativas geradas a partir desse módulo. 
Figura 32 - Módulo D, Grade de Repetição e Estampa.

\section{Módulo D}

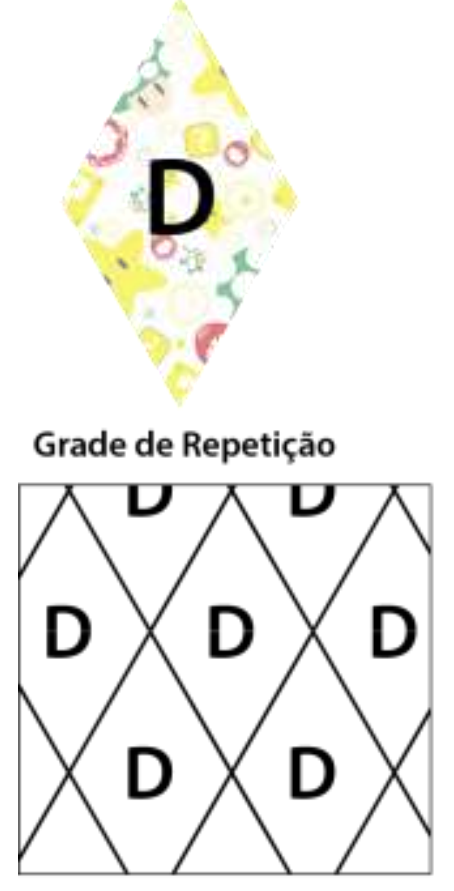

\section{Estampa}

.000000000000

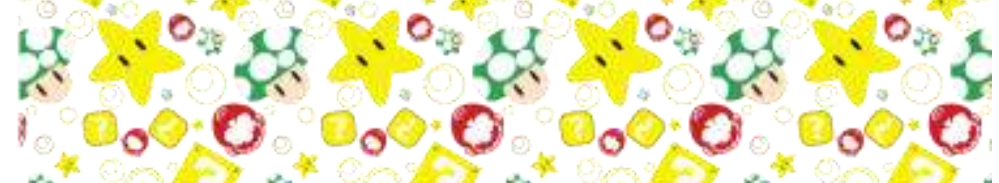

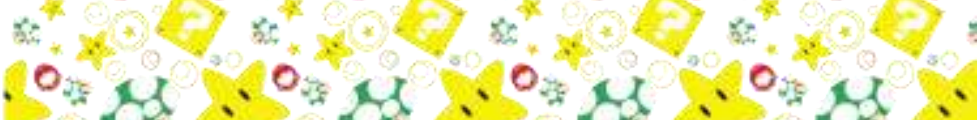

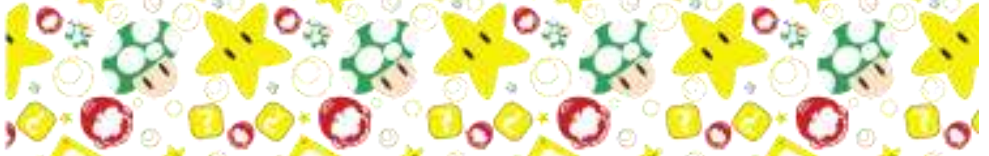

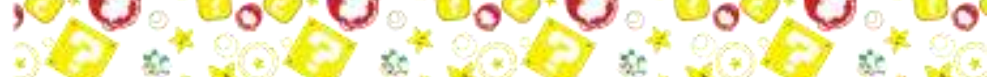

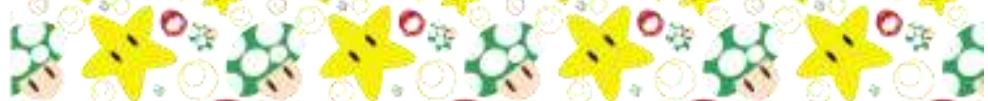
10000000000 $.0 .0 \%: 0.0 \%$ Fonte: Próprio autor. 
Figura 33 - Alternativas geradas a partir das versões do Módulo D.

\section{Módulo D | Versões}
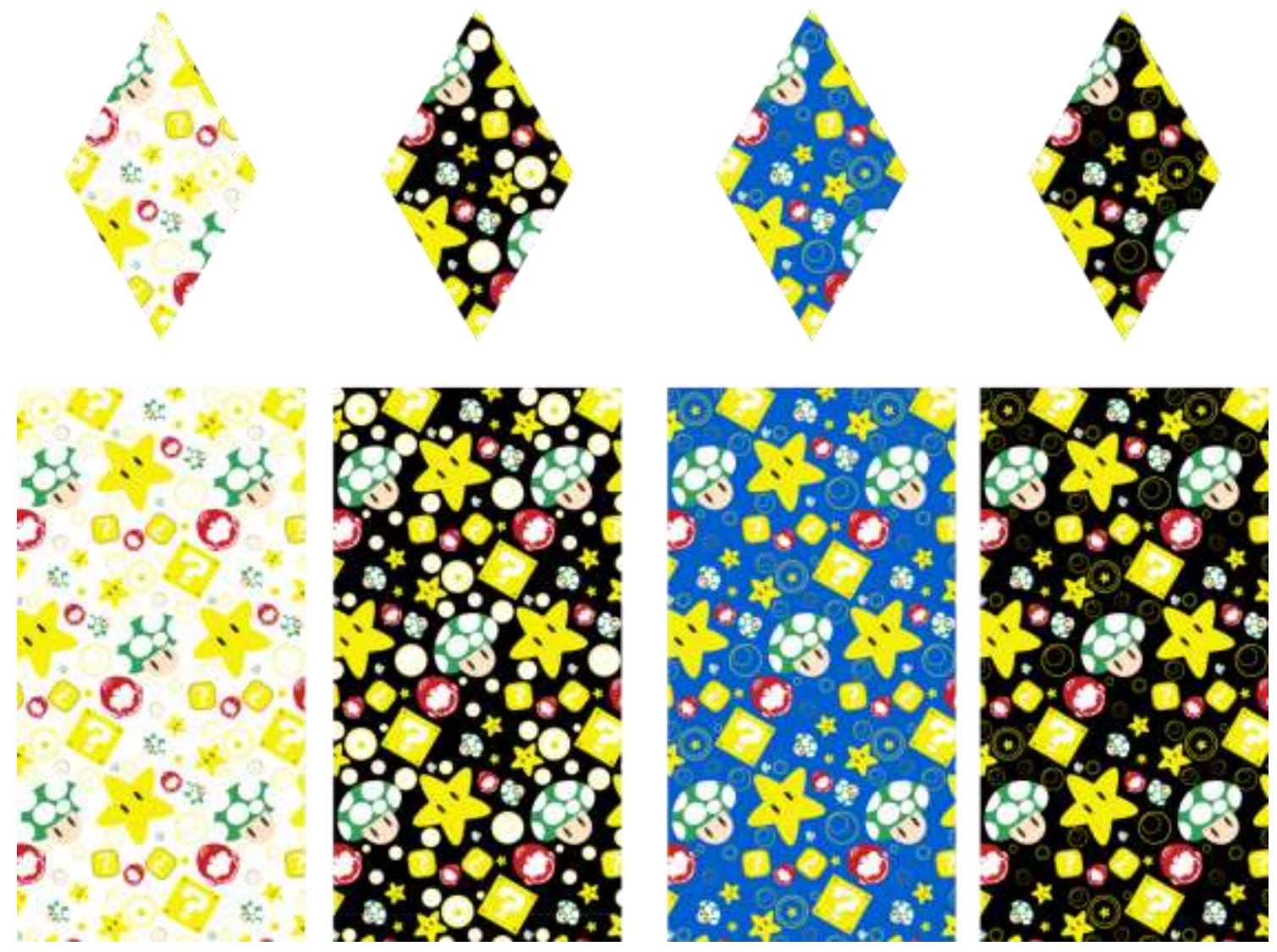

Fonte: Próprio autor.

Como o Módulo E não detêm elementos em suas extremidades isso possibilitou explorar simetrias combinadas ou não, desta maneira a Figura 34 apresenta algumas alternativas modificando a disposição do módulo e/ou a cor do plano de fundo. 
Figura 34 - Módulo E, Grade de Repetição e Estampa.

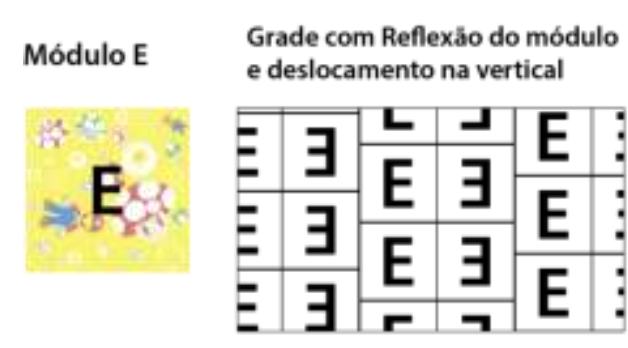

Estampa | alternativa 1

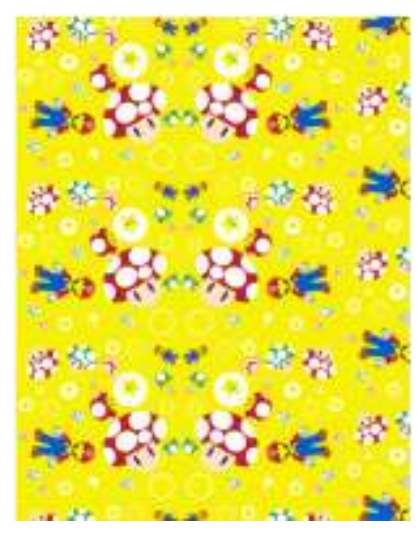

Grade com Rotação do módulo e sem deslocamento

Grade de Reflexăo e sem deslocamento

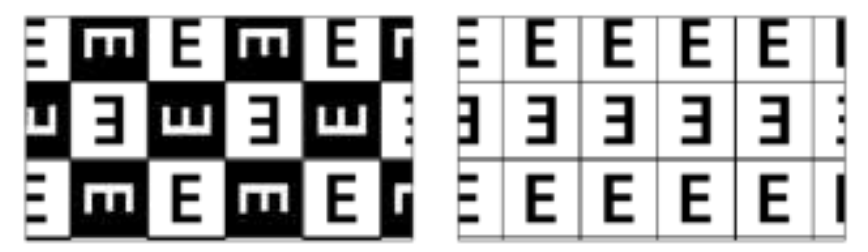

Estampa | alternativa 2

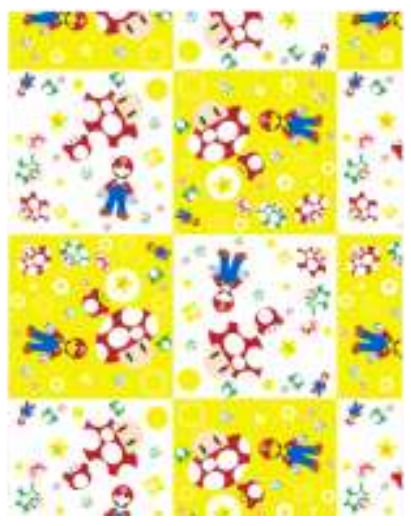

Estampa | alternativa 3

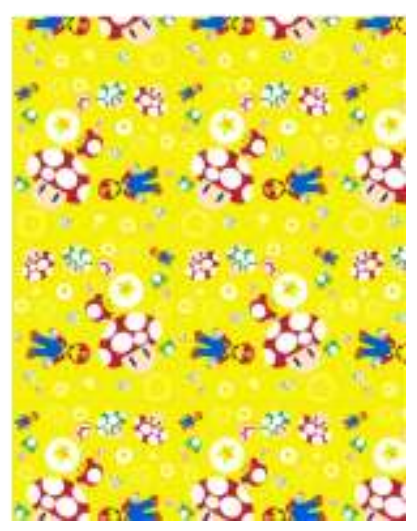

Fonte: Próprio autor.

Foram geradas 18 alternativas no total, com isso, é chegada à fase de Seleção das alternativas que consiste em escolher as mais relevantes a partir de um grupo de sujeitos. Para este trabalho o experimento buscou apresentar para o grupo de 15 pessoas as estampas criadas neste Processo em que os sujeitos deveriam selecionar um total de seis estampas. Sendo que eles tinham que escolher três que eles gostaram e outras três que eles não gostaram. Desta forma, foram selecionadas três estampas com maior pontuação positiva. A Figura 35 apresenta a pontuação individual de cada alternativa. 
Figura 35 - Pontuação das alternativas com destaque em azul destacando as melhores e em vermelhos as reprovadas.
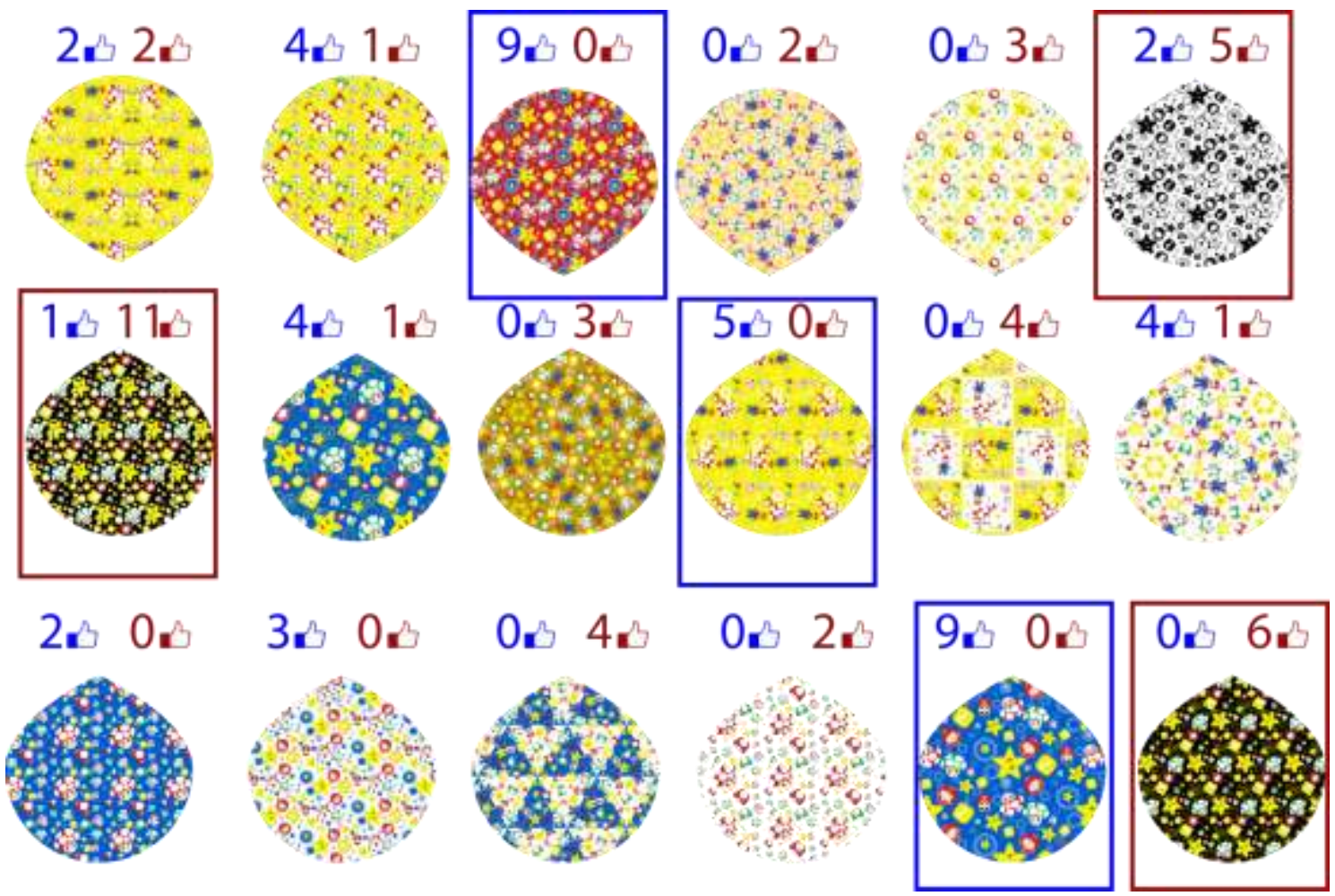

Fonte: Próprio autor.

\section{Conclusão}

Este artigo buscou trazer um conteúdo teórico e prático para designers e/ou estudantes replicarem em seus projetos gráficos, pois é a partir desses conceitos que o designer de superfície tem a base para configura suas estampas. Visto que Rüthschiling (2008) reafirma da relevância do designer se apropriar desses fundamentos, para assim, criar suas estampas.

A relevância deste estudo esta justamente no fato dele trazer outra abordagem de configurar estampa, ou melhor, de apresentar modelos de construção do módulo utilizando de figuras geométricas não convencionais [hexágonos, triângulos, losango], com isso, ampliando o repertório prático do designer/ilustrador e/ou estudante da área. Além disso, procurou-se demonstrar as maneiras incorretas de elaborar o módulo para prevenir possíveis erros durante o processo de construção. 
Cada etapa teve sua importância, pois, procurou setorizar as atividades a serem realizadas em cada fase. Este processo demonstra a fase inicial que esta conectada com a concepção da linguagem visual a ser trabalhada [temática]; por conseguinte as etapas que envolvem o desenvolvimento dos elementos, módulos e alternativas, e por fim, a seleção da estampa. Com isso, almeja-se que este artigo possa colaborar com o desenvolvimento do pensamento projetual, expondo um processo para a configuração de designs de superfícies.

\section{Artigo recebido em Julho de 2015. Aprovado em Setembro de 2015 DOl:http://dx.doi.org/105965/1982615x08172016145}

\section{Referências}

BARBOSA, Ruy Madsen. Descobrindo Padrões em Mosaicos. São Paulo: Atual, 2010.

CIPINIUK, Alberto. Estética. In: COELHO, Luiz Antonio L. Conceitos Chaves em design, Ed. PUC-Rio: Rio de Janeiro, 2011, p. 32 - 35.

CONTÉM DESIGN. Ilustrações Nerds. Página do facebook com o intuito ajudar alunos de design e áreas afins indicando sites, livros, tutoriais, revistas. Disponível em: < https://www.facebook.com/media/set/?set=a.245081355636578.1073741849.24113175 6031538\&type=3\&uploaded=1> Acesso em: 30 de maio de 2013. $2013 \mathrm{a}$.

CONTÉM DESIGN. CultNerd. Página do facebook com o intuito ajudar alunos de design e áreas afins indicando sites, livros, tutoriais, revistas. Disponível em: < https://www.facebook.com/media/set/?set=a.241163156028398.1073741831.24113175 6031538\&type $=3>$ Acesso em: 30 de maio de 2013. 2013b.

CONTÉM DESIGN. Superfícies. Página do facebook com o intuito ajudar alunos de design e áreas afins indicando sites, livros, tutoriais, revistas. Disponível em: < https://www.facebook.com/media/set/?set=a.286316894846357.1073741881.24113175 6031538\&type $=3>$ Acesso em: 30 de maio de 2013. 2013c. 
GOMES, Luiz Antonio Vidal de Negreiros; MACHADO, Clarice Gonçalves da Silva. Design: Experimentos em desenho. 2.ed. Porto Alegre: Ed. UniRitter, 2010.

JABLAN, Slavik V. Theory of Symmetry and Ornament. Beograd: Matematicki Institut, 1995.

LEHMANN, Charles H. Geometria Analítica. São Paulo: Globo, 1998.

LÖBACH, Bernd. Design industrial: bases para a configuração dos produtos industriais. São Paulo: Edgard blücher Ltda., 2001.

RÜTHSCHILLING, Evelise Anicet. Design de Superfície. Porto Alegre: Ed. da UFRGS, 2008.

SUONO, Celso Tetsuro; BERTON, Tamissa Juliana Barreto; PIRES, Gisely Andressa. A Construção de Parâmetros para o Ensino do Desenho de Estamparia Corrida. In: Graphica 2013 - XXI Simpósio Nacional de Geometria Descritiva e Desenho Técnico e X International Conference on Graphics Engineering for Arts and Design, 2013, Florianópolis-SC. Anais do Graphica 2013, 2013.

WONG, Wucius. Princípios de forma e desenho. São Paulo: Editora WMF Martins Fontes, 2010. 